\title{
The genus Xanthogramma Schiner, 1861 (Diptera: Syrphidae) in southeastern Europe, with descriptions of two new species
}

\author{
Zorica Nedeljković, ${ }^{2}$ Antonio Ricarte, ${ }^{1}$ Liiliana Šašić Zorić, Mihajla Đan, \\ Dragana Obreht Vidaković, Ante Vujić
}

\begin{abstract}
Examination of 122 specimens of Xanthogramma Schiner, 1861 (Diptera: Syrphidae) from varied localities in Europe (+ Turkey) resulted in the description of two new species (X. aeginae Ricarte, Nedeljković, and Vujić new species and $X$. pilosum Nedeljković, Ricarte, and Vujić new species), as well as new data on six other species. Most of the examined material originated from the Balkan Peninsula and Greek islands. New species concepts were supported by morphological and molecular evidence. Relationships among the eight studied species were analysed and discussed based on the data of nuclear (ITS2) and mitochondrial (COI) genes sequences. An identification key to the European species of Xanthogramma is provided. Lectotypes are designated for Doros decoratum Zetterstedt, 1843, Lasiophthicus novus Rondani, 1857, Syrphus laetus Fabricius, 1794, Syrphus ornatus Meigen, 1822, and Xanthogramma nobilitatum Frey, 1946.
\end{abstract}

Received 5 October 2017. Accepted 18 January 2018.

Z. Nedeljković, ${ }^{2}$ A. Ricarte, L. Šašić Zorić, BioSense Institute-Research Institute for Information Technologies in Biosystems. Dr Zorana Đinđića 1, 21000 Novi Sad, Serbia

M. Đan, D. Obreht Vidaković, A. Vujić, Department of Biology and Ecology, University of Novi Sad, Faculty of Sciences, Trg Dositeja Obradovića 2, 21000 Novi Sad, Serbia

\footnotetext{
${ }^{1}$ Present address: Centro Iberoamericano de la Biodiversidad (CIBIO), Universidad de Alicante, carretera de San Vicente del Raspeig s/n, 03690 San Vicente del Raspeig, Alicante, Spain

${ }^{2}$ Corresponding author (e-mail: zoricaned14@gmail.com)

Subject editor: Bradley Sinclair

doi:10.4039/tce.2018.21

http://zoobank.org/urn:Isid:zoobank.org:pub:53B81D19-7A8C-4F11-8032-0C466650A526
}

Xanthogramma is present in the Palaearctic, 35 Nearctic, and Oriental regions (Pape and Thompson 36 2013a), with 19 species recorded from the Palaearc- 37 tic (Peck 1988). Violovitsh (1975) provided a 38 diagnosis of the genus. Taxonomy within 39 Xanthogramma remains in flux with the validity of 40 several species still uncertain (Speight 2017). 41 Speight and Sommaggio (2010) provided the 42 first key to all known European species of 43 Xanthogramma, which was reedited by Speight and 44 Sarthou (2017) with modifications to better separate 45 females of $X$. dives (Rondani, 1857), X. pedissequum 46 (Harris, 1776), and X. stackelbergi Violovitsh, 1975. 47 Classical taxonomy is not always conclusive 48 for species delimitation. Additional data sources, such as DNA, can help with this purpose. Mitochondrial DNA (mtDNA) cytochrome $c$ oxidase $\mathrm{I}(\mathrm{COI})$ is frequently used as a molecular marker in taxonomic studies and has proven highly 
informative in elucidating relationships at the species level in Syrphidae (e.g., Ståhls et al. 2009; Marcos-García et al. 2011; Radenković et al. 2011; Vujić et al. 2013; Grković et al. 2015; Nedeljković et al. 2015; Popović et al. 2015; Ačanski et al. 2016; Šašić et al. 2016; Chroni et al. 2017). In addition, registered COI bar codes are useful for molecular identification of species (e.g., Andrić et al. 2014). In Syrphinae taxonomy, the nuclear internal transcribed spacer 2 region (ITS2) is also useful for delimiting species borders, for example in the Chrysotoxum festivum Linnaeus, 1758 species group (Nedeljković et al. 2013) and in the genus Melanostoma Schiner, 1860 (Haarto and Ståhls 2014).

The main aim of the present study is to provide new insights into the systematics of Xanthogramma by integrating species morphology and DNA. Two new species from Greece are described and new distributional data - mainly from southeastern Europe - are provided for six other species.

\section{Material and methods}

Taxonomic study. A total of 122 specimens from Croatia, Czech Republic, Greece, Italy, Macedonia, Montenegro, Serbia, Spain, The Netherlands, and Turkey were studied. To describe and diagnose species, characters were studied with both Ceti (Medline Scientific, Oxfordshire, United Kingdom) and Nikon SMZ 745T (Nikon Corporation, Tokyo, Japan) binocular microscopes. Colour characters always refer to dry specimens. Body size was measured as the length from the tip of the frontal prominence (excluding antenna) to the tip of the abdomen. Wing length was measured from the insertion point on the thorax to the tip of the wing. Antennal size was measured as a relation between the distance from the apex of the basoflagellomere and the most prominent point of the pedicel and the width of the basoflagellomere at the level of the arista base. Measurements were made using an eye-piece micrometer. Morphological terminology follows Thompson (1999), except for the term "proepimeron", which follows Speight and Sarthou (2017). Examined material was identified with Speight and Sommaggio (2010) and Bartsch et al. (2009). A distribution map was created using the software GenGIS (version 2.1.1) (Parks et al. 2013). For type specimens, the symbol " $p$ " separates data from different labels on the same pin.
The numbers in the Examined material sections are part of unique identification labels of the specimens, while numbers with the abbreviation MS refer to the unique identification labels of the specimens used for the molecular analyses.

Examined material belongs to the following collections:

AVE - André Van Eck private collection, Tilburg, The Netherlands

FSUNS - Department of Biology and Ecology, Faculty of Sciences, University of Novi Sad, Serbia

HNHM - Hungarian Natural History Museum, Budapest, Hungary (Dr. Soltész Zoltán)

LSF - Museo Zoologico La Specola, Firenze, Italy (Dr. Luca Bartolozzi)

MAUA - The Melissotheque of the Aegean, University of the Aegean, Mytilene, Greece (Dr. Theodora Petanidou)

MB - Miroslav Barták private collection, Prague, Czech Republic

MCDS - Michael de Courcy Williams private collection, Alexandroupoli, Greece

MNHN - Muséum national d'Histoire naturelle, Paris, France (Dr. Simon Chagnoux)

MZH - Zoological Museum, Finnish Museum of Natural History, Helsinki, Finland (Dr. Gunilla Ståhls)

MZLU - Museum of Zoology, Lund, Sweden (Dr. Rune Bygebjerg)

NHM - Natural History Museum, London, United Kingdom (Dr. Nigel Wyatt)

NHMW - Naturhistorishes Museum Wien, Wien, Austria (Dr. Sehnal Peter)

NMBA - Naturhistorisches Museum der Benediktiner-Abtei, Admont, Austria (Dr. Petr Heřman) WSB - Wouter Van Steenis, Breukelen, The Netherlands

ZISP - Zoological Museum, Academy of Sciences, Russian Academy of Sciences, St. Petersburg, Russia (Dr. Olga Ovtshinnikova)

ZMHB - Zoologishes Museum of Humbolt University, Berlin, Germany (Dr. Sven Marotzke) ZMUC - Zoologisk Museum, Copenhagen, Denmark (Dr. Thomas Pape)

Molecular study. DNA was extracted from two to three legs of 50 Xanthogramma specimens of the eight studied species (see Supplementary Material Table 1) using the SDS extraction protocol (Chen et al. 2010). Sequences of two gene regions ( 3 ' ends of COI and ITS2) were used to 
confirm species boundaries. Polymerase chain reaction amplifications were done using the COI primer pair C1-J-2183 (alias Jerry) and TL2-N-3014 (alias Pat) (Simon et al. 1994), while the ITS2 were amplified using primer pair ITS2A and ITS2B (Beebe and Saul 1995).

Polymerase chain reactions were carried out in $25 \mu \mathrm{L}$ reaction volumes. The reaction mixture contained $1 \times$ Taq Buffer without $\mathrm{MgCl}_{2}$ (ThermoScientific, Vilnius, Lithuania), $2 \mathrm{mM} \mathrm{MgCl}_{2}$, $0.1 \mathrm{mM}$ of each nucleotide, $1.25 \mathrm{U}$ Taq polymerase (ThermoScientific), 5 pmol of each primer, and $\sim 50$ ng template DNA. Amplifications were performed under the following polymerase chain reaction conditions: initial denaturation at $95^{\circ} \mathrm{C}$ for two minutes; 29 cycles of denaturation at $94^{\circ} \mathrm{C}$ for 30 seconds each; 30 seconds annealing at $49^{\circ} \mathrm{C}$; two minute extension at $72{ }^{\circ} \mathrm{C}$; followed by a final extension of eight minutes at $72^{\circ} \mathrm{C}$. Polymerase chain reaction products were enzymatically purified using Exonuclease I and Shrimp Alkaline Phosphatase enzymes (ThermoScientific) according to the instructions of the manufacturer. Sequencing was performed in both directions using the BigDye Terminator v.3.1 cycle sequencing kit (Applied Biosystems, Waltham, Massachusetts, United States of America) at the Sequencing Service Laboratory of the Finnish Institute for Molecular Medicine, Helsinki, Finland.

The resulting DNA sequences were edited for base-calling errors using BioEdit version 7.2.5. (Hall 1999). The alignment of COI sequences was performed manually, while the alignment of the ITS2 fragment was carried out using the L-INS-I strategy as implemented in MAFFT (Katoh and Standley 2013) available on European Bioinformatics Institute bioinformatics framework (McWilliam et al. 2013). Sequences were deposited in GenBank (www.ncbi.nlm.nih.gov/genbank) and their accession numbers are listed in Supplementary Material Table 1. All analyses were rooted on Melanostoma mellinum (Linnaeus, 1758) (accession numbers: KJ848101 for COI, KJ848059 for ITS2), which was used as the outgroup. Variable positions were estimated using DnaSP version 5 (Librado and Rozas 2009). Maximum parsimony analyses were performed using the parsimony ratchet analysis (Nixon 1999) as implemented in TNT (Goloboff et al. 2008; generated from Winclada ASADO (Nixon 2008)), with 2000 iterations per replication and the rest parametres set by default. The bootstrap nodal support values were calculated using non-parametric bootstrapping with 1000 replicates in NONA (Goloboff 1999) spawned with the aid of Winclada ASADO (Nixon 2008).

\section{Results}

Two new species of the genus Xanthogramma are described. New distributional data, mainly from southeastern Europe, are provided for the other six studied species. An identification key to all the known European species of Xanthogramma is presented. Relationships among the studied taxa are analysed based on molecular characters of COI and ITS2 sequences.

\section{Xanthogramma Schiner, 1861}

Xanthogramma Schiner, 1861: 318. Type species Xanthogramma ornatum (Meigen, 1822), now regarded as a synonym of Xanthogramma pedissequum (Harris, 1776-1780). Gender: neuter.

Olbiosyrphus Mik, 1897: 66. Type species Syrphus laetus Fabricius, 1794, now Xanthogramma laetum (Fabricius, 1794).

Philhelius Coquillett, 1910: 378. Type species Musca citrofasciata De Geer, 1776, now of Xanthogramma citrofasciatum (De Geer, 1776).

Taxonomic notes. The name Xanthogramma was erected without included nominal species and instead representing just a group of flies differing from Doros profuges (Harris, 1780) (originally as Doros conopseus (Fabricius, 1775)) in the shape of the ventral part of face and abdomen (Schiner 1860). According to Article 12 of the International Commission on Zoological Nomenclature (1999), the name Xanthogramma was unavailable until a description of this taxon was provided by Schiner (1861). Thus, the genus dates from 1861 and not 1860 , as erroneously assigned by authors such as Pape and Thompson (2013b). Schiner (1861) also included, for the first time, three species in the genus: $X$. citrofasciatum, $X$. ornatum, and $X$. marginale (Loew, 1854). According to Article 67.2.2 of the International Commission on Zoological Nomenclature (1999), these three became the only originally included nominal species in the genus Xanthogramma and were therefore elegible for type fixation. According to Article 69.1 of the International Commission on Zoological Nomenclature (1999), Williston (1887) was the first 
author who subsequently and validly designated one of the originally included nominal species (X. ornatum) as the type species of Xanthogramma, by stating "Type of genus $X$. ornata Meigen".

Olbiosyrphus Mik, 1897, was previously considered an independent but related genus (Dušek and Láska 1967), but is now considered a synonym of Xanthogramma (Vockeroth 1969).

Diagnosis. Xanthogramma adults are relatively large flies with the following charaters. Head: short antenna and oval basoflagellomere; thorax: with sharply defined, bright yellow markings on the scutum laterally and katepisternum; postpronotum bare, anterior anepisternum bare, metapleuron bare ventral to spiracle, scutellum black basally (yellow apically), extensively microtrichose wing, with vein $\mathrm{R}_{4+5}$ straight or nearly so, calypter bare; abdomen: never distinctly petiolate, nearly flat, black and with yellow markings, emarginate at least on tergum 4 and tergum 5 (Thompson and Rotheray 1998).

Xanthogramma flies resemble those of the genera Sphaerophoria LePeletier and Serville, 1828; Doros Meigen, 1803; Epistrophe Walker, 1852; and Chrysotoxum Meigen, 1803. From Sphaerophoria, Xanthogramma can be distinguished by a strongly emarginate abdomen (at least on tergum 4 and tergum 5) (Thompson and Rotheray 1998); from Doros, by the absence of an abdominal waist (Van Veen 2004) and vein $\mathrm{A}_{1}$ dipped into the anal cell before tip (this vein is almost straight before apex in Doros) (Láska et al. 2013); from Epistrophe, by the presence of yellow maculae on the thoracic pleuron, which are absent in Epistrophe; and finally, from Chrysotoxum, by the length of the antennae, which are much shorter in Xanthogramma (Van Veen 2004).

Morphologically, the most similar genus to Xanthogramma is Citrogramma Vockeroth, 1969, but in Xanthogramma the subscutellar fringe is absent, the metasternum is bare, the antennal base is more promanent than the oral apex and the lateral yellow vitta of the scutum does not reach the scutellum (Mengual 2012).

\section{European Xanthogramma species}

Xanthogramma aeginae Ricarte $\supseteq$
Nedeljković, and Vujić, new species

Figs. 1-2, 7, 12, 27, 31.

Type material. Holotype: $\widehat{o}$, "Greece, Chios, Palios Katarraktis, 8-10.iv.2012, leg. M. Taylor, $38.254^{\circ} \mathrm{N}, \quad 26.086^{\circ} \mathrm{E}, \quad$ UOTA-MEL， 028881 , (MS104)" (deposited in FSUNS).

Paratypes: Greece, 10, Lesvos, $2.2 \mathrm{~km} \mathrm{SE}$ Mystegna, $10 \mathrm{~m}, 39.204^{\circ} \mathrm{N}, 26.485^{\circ} \mathrm{E}$, Phrygana Simple (Aegean University 0037398) (MS83) (MAUA); 10, 2ㅇ, Chios, Ermioni-Thymiana, 5-7.iv.2012, Taylor, $38.309^{\circ} \mathrm{N}, 26.141^{\circ} \mathrm{E}, 2525$ (1ð), UOTA-MEL 028941 (MS105), 2521 (1\%), 7.iv.2012, Taylor, 3971, UOTA-MEL 038479 (19) (MS108) (MAUA); 10, Chios, Palinaeon II, 30.iv-2.v.2012, Taylor, $38.575^{\circ} \mathrm{N}, 26.004^{\circ} \mathrm{E}$, 2673, UOTA-MEL 027833 (MS106) (MAUA); 10, 3ㅇ, Chios, Managros, 29-30.v.2012 (10), Poutziakas, $38.4638^{\circ} \mathrm{N}, 25.937^{\circ} \mathrm{E}, 2928$, UOTAMEL 026609, 29.iii.2012 (19), Toutziarakis, 29-30.iii.2012, Toutziarakis, UOTA-MEL 026610 (19), UOTA-MEL 026621 (19) (MAUA); 10, 1ㅇ, Chios, Gridia, 8-10.iv.2012, Taylor, $38.216^{\circ} \mathrm{N}, 26.102^{\circ} \mathrm{E}, 2413$, UOTA-MEL 027050 (10َ), UOTA-MEL 027051 (MS110) (19) (MAUA); 19, Chios, Armolia, 3-5.iv.2012, Taylor, $\quad 38.272^{\circ} \mathrm{N}, \quad 26.044^{\circ} \mathrm{E}, \quad$ UOTA-MEL 026894 (MS107) (MAUA); 10, 3ㅇ, Chios, Palios Katarraktis, $8-10 . i v .2012$, Taylor, $38.254^{\circ} \mathrm{N}$, $26.086^{\circ} \mathrm{E}, 2517$, UOTA-MEL 028890 (10), 2514, UOTA-MEL 028906 (19), 2510, UOTA-MEL 029138 (19), 2511, UOTA-MEL 028916 (19) (MAUA); 1ㅇ, Chios, Kampia Castle, 29-30. iii.2012, Toutziarakis, $38.581^{\circ} \mathrm{N}, 25.981^{\circ} \mathrm{E}, 2948$, UOTA-MEL 026830, (MS109) (MAUA).

Diagnosis. Length $=12.2-12.3 \mathrm{~mm}$; eyes with very short, sparse, yellow pile; frontal triangle with black pile; scutellum with long, yellow pile; notopleuron yellow, at most narrowly black near the anterior anepistenum; posterior anepisternum with a yellow macula in the posterior part; katepisternum, katatergum, proepimeron with a small, yellow macula each; posterior anepisternum with yellow macula in the posterior part; scutellum yellow, only black at the posterior corners and transparent yellow at the anterior part, mainly with long, black pile anteriorly and yellow pile posteriorly; wing cell $\mathrm{R}_{1}$ brown pigmented; terga 2-4 each with a pair of yellow fasciae reaching the lateral margins; tergum 2 fasciae triangular with a low rounded median projection.

Xanthogramma aeginae can be distinguished from the similar $X$. citrofasciatum by the presence of a yellow macula on the proepimeron, which is completely black in X. citrofasciatum (Table 1 ). The pile of the posterior anepisternum are all 
Figs. 1-4. Xanthogramma species, overall appearance, dorsal view. 1, Xanthogramma aeginae, male holotype; 2, Xanthogramma aeginae, female paratype; 3, Xanthogramma pilosum, male holotype; 4, Xanthogramma pilosum, female paratype.
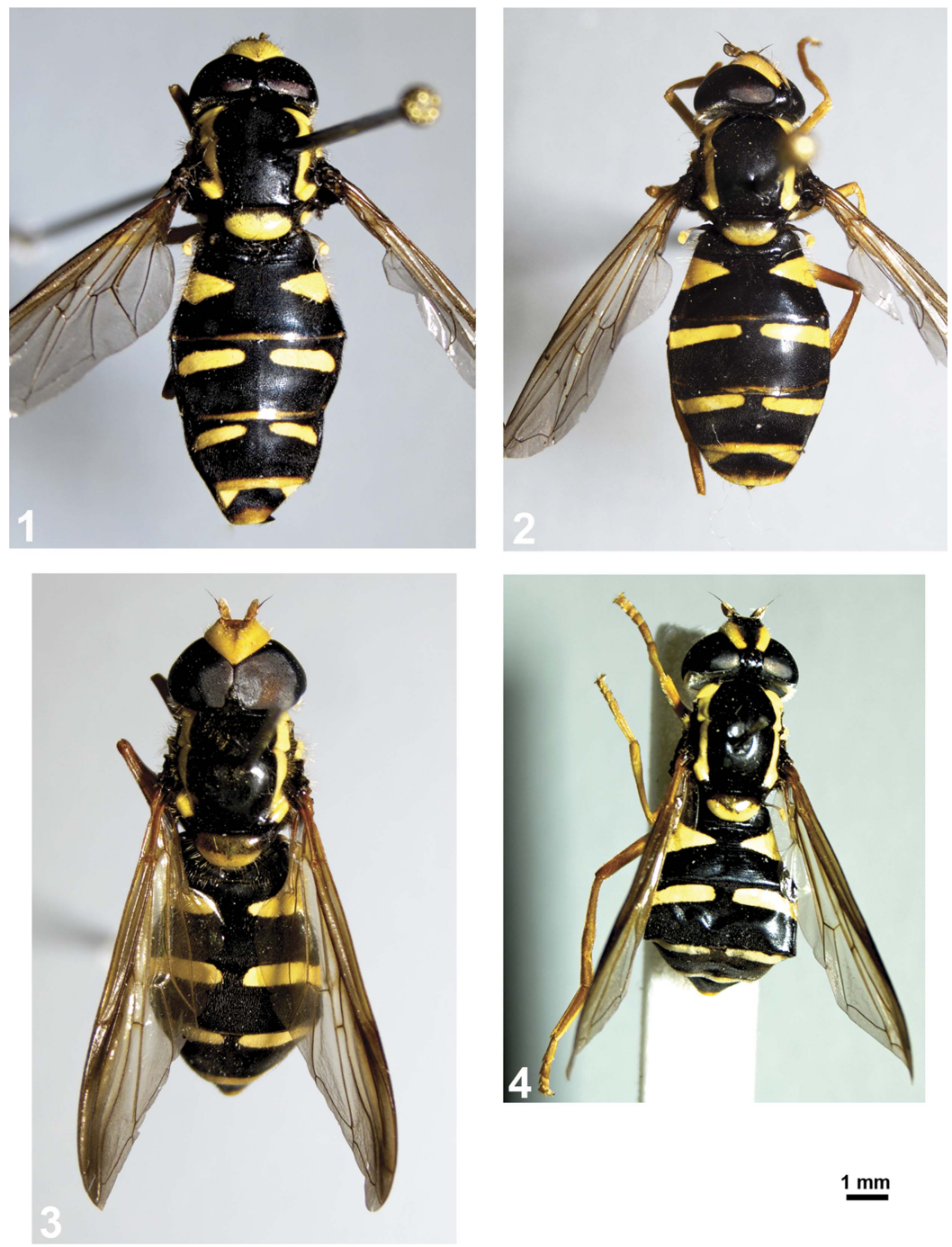

black in $X$. aeginae, but mainly yellow in $X$. citrofasciatum.

Description. Male (Figs. 1, 7, 12). Length = $12.2-12.3 \mathrm{~mm}$, Wing length $=8.2 \mathrm{~mm}$. Head. Eyes with very short, sparse, yellow pile; frontal triangle yellow with black pile; vertical triangle black with black pollinosity and black pile; ocellar triangle nearly equilateral; occiput black pollinose along eye margin, with long black pile in dorsal part and yellow pile in ventral part; lunule dark yellow and transparent; antenna yellow to dark orange, scape and pedicel yellow with short, black pile; basoflagellomere oval, dark orange, black in dorsal part; arista yellow with short pile (length of cross-section of apical part of arista); face yellow with black pile in dorsal and ventral parts and with yellow pile in medial part; ventral part of gena yellow (only black at lateral corners) with black pile; occiput white pollinose, with long, black pile in dorsal part and yellow pile in medial and ventral parts. Thorax (Figs. 7, 27). Scutum black with two faint silverish-pollinose vittae extending for anterior two-thirds of scutum length; scutum with long, yellow pile in anterior half and intermixed yellow and black pile in posterior half; notopleuron yellow, at most narrowly black near
366 
Table 1. Diagnostic morphological differences between Xanthogramma citrofasciatum and Xanthogramma aeginae.

\begin{tabular}{|c|c|c|}
\hline Character & X. citrofasciatum & $X$. aeginae \\
\hline \multicolumn{3}{|l|}{ Males and females } \\
\hline Mesonotum & With short, yellow pile (Fig. 28) & $\begin{array}{l}\text { With long, yellow pile anteriorly and long, } \\
\text { black pile posteriorly (Fig. } 27 \text { ) }\end{array}$ \\
\hline Notopleuron & $\begin{array}{l}\text { Yellow dorsally and black } \\
\text { ventrally (Fig. 8) }\end{array}$ & Yellow (Fig. 7) \\
\hline Katepisternum & $\begin{array}{l}\text { Black or with small yellow } \\
\text { macula (Fig. } 8 \text { ) }\end{array}$ & Always with yellow macula (Fig. 7) \\
\hline Proepimeron & Black (Fig. 8) & With yellow macula (Fig. 7) \\
\hline Colour of pile on femora & Yellow & Black \\
\hline $\begin{array}{l}\text { Shape of maculae } \\
\text { on tergum } 2\end{array}$ & $\begin{array}{l}\text { Rectangular with more rounded } \\
\text { medial apex (Fig. 9) }\end{array}$ & $\begin{array}{l}\text { Triangular with pointed medial apex } \\
\quad \text { (Figs. 1, 12) }\end{array}$ \\
\hline \multicolumn{3}{|l|}{ Males } \\
\hline $\begin{array}{l}\text { Maculae on tergum } 3 \text { and } \\
\text { tergum } 4\end{array}$ & $\begin{array}{l}\text { Reaching lateral margins of terga } \\
\text { (Fig. 9) }\end{array}$ & $\begin{array}{l}\text { Not reaching lateral margins of terga } \\
\quad \text { (Figs. 1, 12) }\end{array}$ \\
\hline
\end{tabular}

anterior anepistenum, lateral margin of scutum black posteriorly to transverse suture; notopleuron with intermixed long black and yellow pile; anterior anepisternum with small, yellow macula ventrally; posterior anepisternum with yellow macula in posterior part, anterior anepisternum with long, black pile in dorsal part and yellow pile in ventral part; proepimeron, katepisternum, katatergum with small, yellow macula (Fig. 7); legs completely yellow; femora with black pile; tibiae and tarsi with yellow pile; scutellum yellow, only black at posterior corners and transparent yellow in anterior part, scutellum mainly with long, black pile anteriorly and yellow pile posteriorly; wing membrane extensively microtrichose, wing cell $\mathrm{R}_{1}$ brown pigmented.

Abdomen (Figs. 1, 12). Black with short, black pile, except tergum 1, anterior part of tergum 2 and yellow fasciae of all terga yellow pilose; sternum 1 black with narrow yellow fascia in posterior part; sternum 1 with long, yellow pile; sternum 2 black; anterior part of sternum 2 with two yellow, triangular maculae covered with yellow pile; posterior part of sternum 2 with narrow, yellow maculae covered with black pile; medial part of sternum 2 with yellow pile; sternum 3 with two yellow, rectangular fasciae connected in the middle with yellow pile and yellow fasciae in the posterior part with black pile, medial part of sternum 3 covered with black pile; sternum 4 black with two yellow maculae in the anterior part, connected in the middle, covered with black pile; medial and posterior parts of sternum 4 black pilose; sternum 5 black, with yellow fasciae in the anterior and posterior parts, sternum 5 with black pile; sterna completely surrounded by membrane. Male genitalia (Fig. 31). Surstylus square shaped, with "V" notch in upper part. Hypandrium 2 times longer than wide.

Female (Fig. 2). Length $=12.3 \mathrm{~mm}$. Similar to male except for the following characters: black vitta extending from ocellar triangle to lunule; face yellow with long, black pile medially and yellow pile laterally; frons with long, black pile; ocellar triangle black with long, black pile.

Etymology. The name "aeginae" refers to Aegina (A $\gamma \imath v \alpha$, in Greek), wife of Zeus (Zzús, in Greek) in Greek mythology, because the type locality is in Greece.

Distribution and habitat (Fig. 38). Greece (the Aegean islands of Lesvos and Chios). This species inhabits Mediterranean forest and shrub areas.

Natural history. Adults fly from the end of March to the beginning of May. Larvae are unknown.

\section{Xanthogramma citrofasciatum (De Geer, 1776)}

Figs. 8-9, 28.

Musca anteambulo Harris, 1776: 60. Junior synonym. 
Figs. 5-8. Xanthogramma species, thorax, lateral view. 5, Xanthogramma pilosum, male holotype; 6, Xanthogramma laetum, male; 7, Xanthogramma aeginae, male holotype; 8, Xanthogramma citrofasciatum, male.
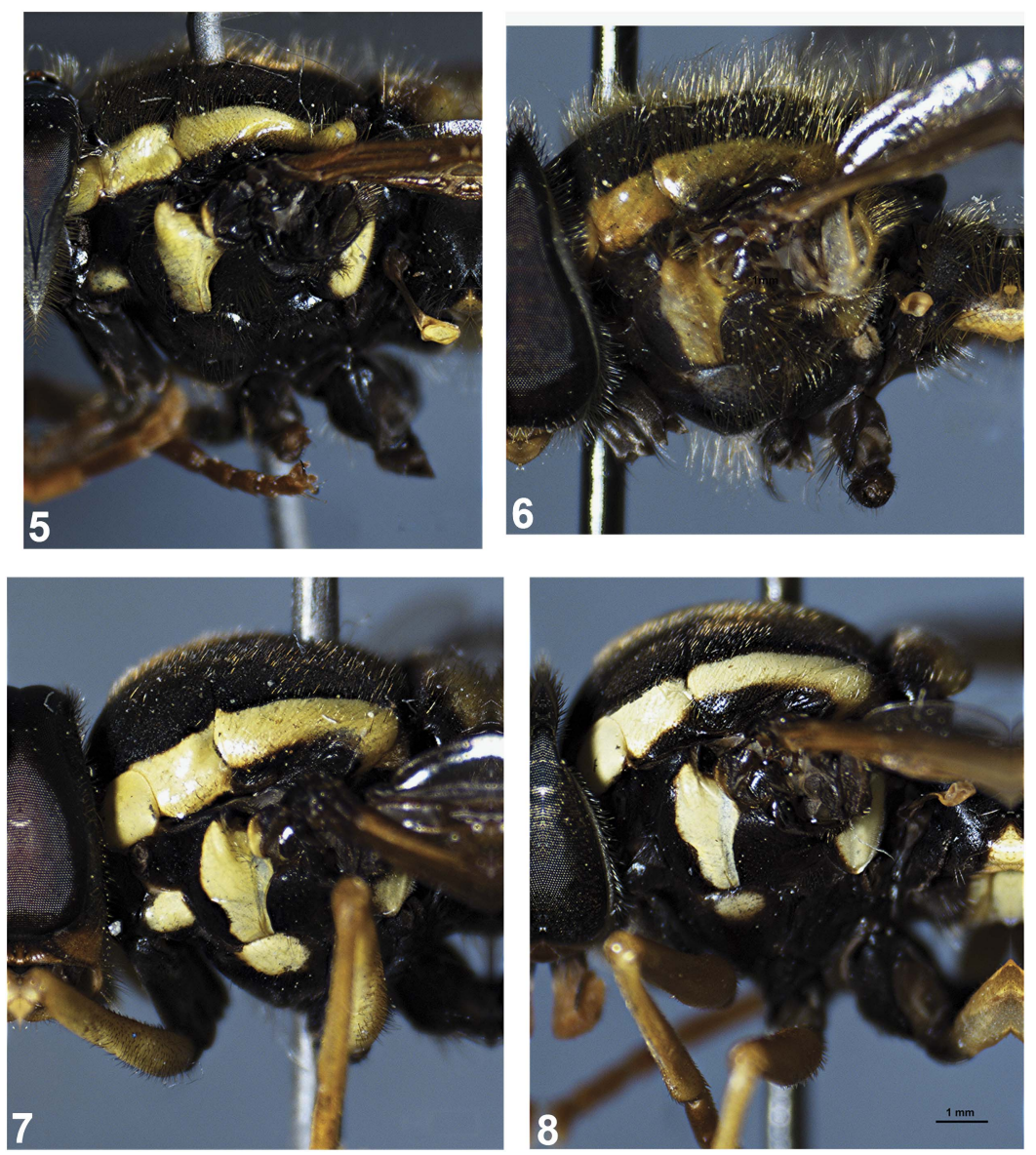

Figs. 9-12. Xanthogramma species, abdomen, dorsal view. 9, Xanthogramma citrofasciatum; 10, Xanthogramma laetum; 11, Xanthogramma pilosum, male holotype; 12, Xanthogramma aeginae, male holotype.

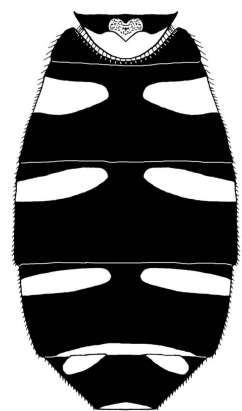

9

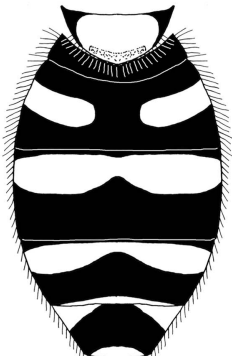

10

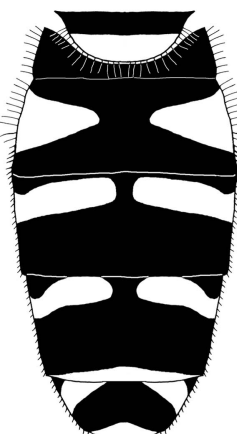

11

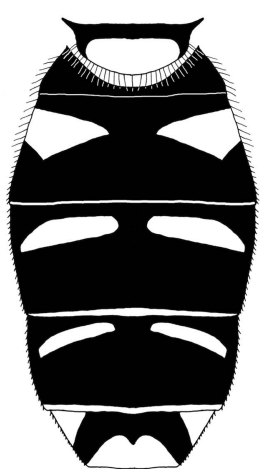

12 
Syrphus philanthinum Illiger in Rossi, 1807: 450. Junior synonym.

Material examined. The invalid lectotype of Musca festiva Linnaeus, 1758 (this lectotype was invalidated by International Commission on Zoological Nomenclature (2001)): 1 male labelled as "festiva 33" [red label], "LECTOTYPE/Musca festiva Linné/Design. Thompson 1981" [yellow label] (The Linnaean Collections, London, United Kingdom). Croatia: $1 \delta^{\star}$, Primorje, Trogir, 7. iv. $1978,43.517^{\circ} \mathrm{N}, 16.249^{\circ} \mathrm{E}$ (FSUNS); Greece: 10, Trigono, 11.v.1990, $40.738^{\circ} \mathrm{N}, 21.204^{\circ} \mathrm{E}$ (FSUNS); 10, Pieria, Mount Olympus, Stragos, 7-14.vi.2014, M. Minachilis, $40.105^{\circ} \mathrm{N}, 22.412^{\circ} \mathrm{E}$ (MAUA); 19, Pindos, Katara Pass, 15.v.2011, $39.796^{\circ} \mathrm{N} 21.229^{\circ} \mathrm{E}$, Vujić (MS80) (FSUNS); 1웅, Mount Olympus, Litochotas-Prionia, 18.v.2011, $40.11^{\circ} \mathrm{N} 22.46^{\circ} \mathrm{E}$, Vujić (MS79) (FSUNS); 1ㅇ, Drama, Sidironero, 18.v.2011, $41.312^{\circ} \mathrm{N} 24.220^{\circ} \mathrm{E}$, Vujić (MS78) (FSUNS); 10, Aegean islands, Lesvos, Ag. Marina, 1.iv.2015, J. Devalez, $39.063^{\circ} \mathrm{N}$, $26.576^{\circ} \mathrm{E}$ (MAUA); $10^{\circ}$, Chios, Palios Katarraktis, $12-14 . i v .2013$, G. Nakas, $38.255^{\circ} \mathrm{N}, 26.086^{\circ}$ E (MAUA); Macedonia: 2 ${ }^{\star}$, Baba Mountain, 20. iv. $1990, \quad 41.0032^{\circ} \mathrm{N}, \quad 21.185^{\circ} \mathrm{E}$ (FSUNS); Montenegro: 19, Durmitor, Komarnica-Nevidio, 3.v.2009, Vujić, $42.98^{\circ} \mathrm{N} 19.068^{\circ} \mathrm{E}$ (MS77) (FSUNS); 19, Durmitor, Sušičko jezero, 31. v.2011, Vujić, $43.14^{\circ} \mathrm{N} \quad 18.99^{\circ} \mathrm{E}$ (MS40) (FSUNS); Serbia: 1 ${ }^{\star}$, Fruška gora, Glavica, 25. iv. $1989,45.153^{\circ} \mathrm{N}, 19.834^{\circ} \mathrm{E}$ (FSUNS) (published in Vujić and Glumac 1994); 10َ, Fruška gora, Stražilovo, 25.iv.2009, $45.17^{\circ} \mathrm{N} 19.97^{\circ} \mathrm{E}$, Nedeljković (MS103) (FSUNS); 20, Stara planina, Dojkinačka reka, 6.v.1988 (1ठ), 29-30. v.1988 $\left(10^{\star}\right), 43.220^{\circ} \mathrm{N}, 22.809^{\circ} \mathrm{E}$ (FSUNS); $20^{\star}$, Topli Do-Pilj, 28.v.1987, 43.352 ${ }^{\circ} \mathrm{N}, 22.681^{\circ} \mathrm{E}$ (FSUNS); 1 $0^{\dagger}$, Dubašnica, Mikuljska reka, 4. vi.1993, Radišić, $44.018^{\circ} \mathrm{N}, 21.906^{\circ} \mathrm{E}$ (FSUNS); 4ðَ, Lunga, 15.v.1994, Radenković, $44.014^{\circ} \mathrm{N}$, $21.894^{\circ} \mathrm{E}$ (FSUNS); 9ㅊ, 4우, Demizlok, 30.

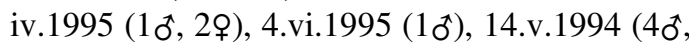
1ㅇ), 20.v.1996 (3ð, 1ㅇ), $44.018448^{\circ} \mathrm{N}, 21.889^{\circ} \mathrm{E}$ (FSUNS); 10, 1, Dubašnica, Klisura Lazareve reke, 5.v.2012, Vujić (MS33, MS37) (FSUNS); 2§o, 2o, Malinik, prema Vidikovcu, 3.v.2012, Vujić, $44.001^{\circ} \mathrm{N} 21.902^{\circ} \mathrm{E}$ (MS34, MS35, MS36, MS38) (FSUNS); 10َ, Beljavina, 6.vi.1993, $44.085104^{\circ} \mathrm{N}, 21.939197^{\circ} \mathrm{E}$ (FSUNS); $10^{\star}, 1$ 웅, Manastirište, 29.iv.1995 (10), 3.v.2012 (1o) (MS39), $\quad 44.018^{\circ} \mathrm{N}, \quad 21.961^{\circ} \mathrm{E}, \quad$ leg. Vujić
(FSUNS); 4ðૈ, Malinik, 13.v.1994 (1ઠð), 1.v.1995

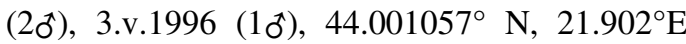
(FSUNS); 2ð, Malinik, ka Vidikovcu, 3.v.1996, $44.001^{\circ} \mathrm{N}, \quad 21.902^{\circ} \mathrm{E} \quad(\mathrm{FSUNS}) ; \quad 20^{\circ}, \quad 1 \%$, Seličevica, $16 . i v .1989, \quad 43.238^{\circ} \mathrm{N}, \quad 21.927^{\circ} \mathrm{E}$ (FSUNS); 2ð, Šar planina, Brezovica, 14.v.1997, Vujić and Radenković, $42.183165^{\circ} \mathrm{N}, 21.050^{\circ} \mathrm{E}$ (FSUNS); 10, Deliblatska peščara, Tilva, 25. iv.1998, Radišić, $44.947^{\circ} \mathrm{N}, 20.965^{\circ} \mathrm{E}$ (FSUNS); 10ิ, Alibunar-slatina, 22.iv.1988, $45.055^{\circ} \mathrm{N}$, $20.969^{\circ} \mathrm{E}$ (FSUNS); $10^{\star}, 1$ \% , Kopaonik, Vujkovci, 1.v.1992, $43.338^{\circ} \mathrm{N}, 20.947^{\circ} \mathrm{E}$ (FSUNS); $10^{\text {๙ }}$, Samokovska reka, 24.v.1992, $43.331^{\circ} \mathrm{N}, 20.739^{\circ}$ E (FSUNS); 10, Kokorovac, 26.v.1987; 1ㅇ, Radošice, 30.iv.1992, $43.274^{\circ} \mathrm{N}, \quad 20.797^{\circ} \mathrm{E}$ (FSUNS); $10^{\star}$, Suva planina, Bojanine vode, 2. v.1988, $43.225^{\circ} \mathrm{N}, 22.117^{\circ} \mathrm{E}$ (FSUNS); Turkey: 19, Manisa, Kula, 18.iii.2014, J. Devalez, 38.607 $\mathrm{N}, 28.801^{\circ} \mathrm{E}$ (MAUA); 40`, 19, $11 \mathrm{~km}$ E of Mugla, 1310 m, 1.v.2013, Barták and Kubik (MB).

Remarks. The holotype of Xanthogramma anteambulo (Harris, 1776) has not been checked because the Harris collection is probably lost $(\mathrm{N}$. Wyatt, The Natural History Museum, London, United Kingdom, personal communication). The original description of Xanthogramma anteambulo matches $X$. citrofasciatum based on examination of the original publication (Harris 1776-1780: 60, fig. 17). The original type material of Xanthogramma citrofasciatum described by De Geer (1776) has presumably been lost or destroyed (N. Wyatt, personal communication). Xanthogramma philanthinum (Illiger in Rossi, 1807) was described under the genus Syrphus, later transferred to Xanthogramma by Bezzi and Stein (1907). We have searched for this type specimen in many collections $(\mathrm{ZMHB}, \mathrm{ZFMK}=$ Zoologishes Forschungsmuseum Alexander Koenig, Germany, $\mathrm{SNMB}=$ Staatlishes Naturhistorisches Museum Braunschweig, Germany, LSF, MNM=Museo Civico di Storia Naturale di Milano, Italy) and we could not find it. According to Article 75.3 of the International Commission on Zoological Nomenclature (1999), a neotype is validly designated when there is an exceptional need. At the moment, $X$. citrofasciatum is not involved in any complex zoological problem and there is no doubt about its identity. Xanthogramma aeginae is similar to $X$. citrofasciatum but they can be easily separated by traditional morphology (see under diagnosis of $X$. aeginae), since they are not cryptic or sibling 
species. Comparisons, figures and keys provided in the present paper serve to fix the concept of $X$. citrofasciatum without need of a neotype designation.

Distribution. From southern Norway south to the Iberian Peninsula; from Ireland eastwards through central and southern Europe into European Russia and the former Yugoslavia; the Caucasus; western Siberia (Speight 2017).

Natural history. Adults fly from March to June. Larva undescribed but known to prey on aphids (Hemiptera: Aphididae) living in Lasius Fabricius, 1804 (Hymenoptera: Formicidae) nests (Speight 2017).

\section{Xanthogramma dives (Rondani, 1857)}

Syrphus dives Rondani, 1857: 136.

Material examined. Greece: $2{ }^{\star}$, Lesvos, Agiassos, Sanatorio, 13.iv.2013, $39.07^{\circ} \mathrm{N}$, $26.386^{\circ} \mathrm{E}$ (MS70, MS74), (FSUNS); $10^{\star}$, Samos, Neochori, 16.iv.2011, Vujić and Radenković, $37.70^{\circ} \mathrm{N} 26.76^{\circ} \mathrm{E}$ (MS67), (FSUNS); Italy: 1 , Toscana, Caniparola, 15.v.2012, $44.112^{\circ} \mathrm{N}$, $10.011^{\circ} \mathrm{E}$, Vujić and Likov (MS54); Montenegro: 1, Orjen, 1.vi.2011, Vujić (MS48) (FSUNS); 10, Boka Kotorska, Morinj, 8-10. v.2010, $42.49^{\circ} \mathrm{N}, \quad 18.64^{\circ} \mathrm{E}, \quad$ Vujić (MS52) (FSUNS); Serbia: $1 \delta^{\star}$, Mokrin, Pašnjaci velike droplje, 7.vi.2016, $\quad 45.925^{\circ} \mathrm{N}, \quad 20.298^{\circ} \mathrm{E}$, Nedeljković and Tot (MS144) (FSUNS); 10, Fruška gora, Šakotinac, vii.2010, Vujić (MS62) (FSUNS); 10, Kovilj, Blizu manastira, 4. vii.2011, $45.213^{\circ} \mathrm{N}, 20.0370^{\circ} \mathrm{E}$, Vujić (MS56) (FSUNS); 10, Pčinja, Vogance, 18.vi.2012, $42.351^{\circ} \mathrm{N}, 21.913^{\circ} \mathrm{E}$, Vujić (MS61) (FSUNS).

Distribution. Uncertain due to confusion between $X$. pedissequum and X. stackelbergi. This species has been confirmed from Spain, France, The Netherlands, Germany, Switzerland, Italy, and Norway (Speight 2017).

Natural history. Adults fly from May to midJune and from July to the beginning of September. The larva is not described (Speight 2017).

Remarks. The lectotype of $X$. dives, confirmed and designated by Speight and Sommaggio (2010), was examined from high-resolution photographs of the head, thorax, and abdomen (dorsal and lateral views). Label data: "Lectotypus/
Syrphus dives Rondani/design. C. Kassebeer 1992" (LSF).

\section{Xanthogramma laetum (Fabricius, 1794)}

Figs. 6, 10, 23, 29.

Syrphus laetus Fabricius, 1794: 301.

Lasiophthicus novus Rondani, 1857: 140. Junior synonym.

Material examined. Published material: Serbia: 1ㅇ, Fruška Gora, Stari Ledinci, 10. v. $1957,45.196^{\circ} \mathrm{N}, 19.787^{\circ} \mathrm{E}$ (FSUNS); 1 \% Fruška Gora, Stražilovo, 16.v.1982, 45.176º N, $19.971^{\circ} \mathrm{E}$ (FSUNS) (published in Vujić and Glumac 1994); 10, Serbia, Obedska bara, Kupinovo, 23.iv.1986, $44.714^{\circ} \mathrm{N}, 20.048^{\circ} \mathrm{E}$ (FSUNS) (published in Vujić et al. 1998). Montenegro: 10, Durmitor, Sušičko jezero, 16-17.v.2001, Vujić, $43.140^{\circ} \mathrm{N}, 18.999^{\circ} \mathrm{E}$ (FSUNS). New material: Czech Republic: 20ิ, Vráž near Pisek, $400 \mathrm{~m}$, near brook, Malaise trap, 10.v-4.vi.2011, M. Barták, $49.399^{\circ} \mathrm{N}, 14.133^{\circ} \mathrm{E}$ (MB); 2ᄋ, Vráž near Pisek, 400 m, Pyramidal trapwood, 11.iii-11. iv.2014 (19), 6.vi-25.viii.2012. (19), $49.399^{\circ} \mathrm{N}$, $14.133^{\circ} \mathrm{E}, \mathrm{M}$. Barták (MB); The Netherlands: 10, Li Savelsbos, 19.v.2012, Van Eck (AVE); 1ㅇ, Valkenburg, Schaelsberg, 26.iv.2007, 50.861 ${ }^{\circ} \mathrm{N}$, $5.831^{\circ} \mathrm{E}$, W. Van Steenis (MS149) (WSB); Spain: $1{ }^{\star}$, Alava, Delika, 29.iv.2016, $42.967^{\circ} \mathrm{N}$, $2.988^{\circ} \mathrm{W}$, Van Eck (MS148) (AVE).

Type material examined. Lectotype (here designated in order to fix identity of the species) of Xanthogramma laetum (Fabricius, 1794) “p. 243 47” [yellow label]/“laetus" (handwritten)/ "LECTOTYPUS Syrphus laetus Fabricius design. C. Kassebeer 1992" [yellow label] (ZMUC) (Figs. 13-15).

Lectotype (here designated in order to fix identity of the species) of Xanthogramma novum (Rondani, 1857) - "Museo "La Specola""/"Coll. Rondani"/“SYNTYPUS" [red label], "LECTOTYPUS/Lasiopthicus novus Rondani/design C. Kassebeer 1992" [yellow label], "228" [white label] (LSF) (Figs. 16-18).

Remarks. The lectotype of $X$. laetum was examined from high-resolution photographs of the head and thorax (dorsal and lateral views). The lectotype is in very poor condition, lacking legs and abdomen. Although the lectotype of $X$. laetum was labelled as such by Kassebeer, this 
Figs. 13-15. Syrphus laetus (=Xanthogramma laetum), lectotype. 13, dorsal view; 14, lateral view; 15, labels.

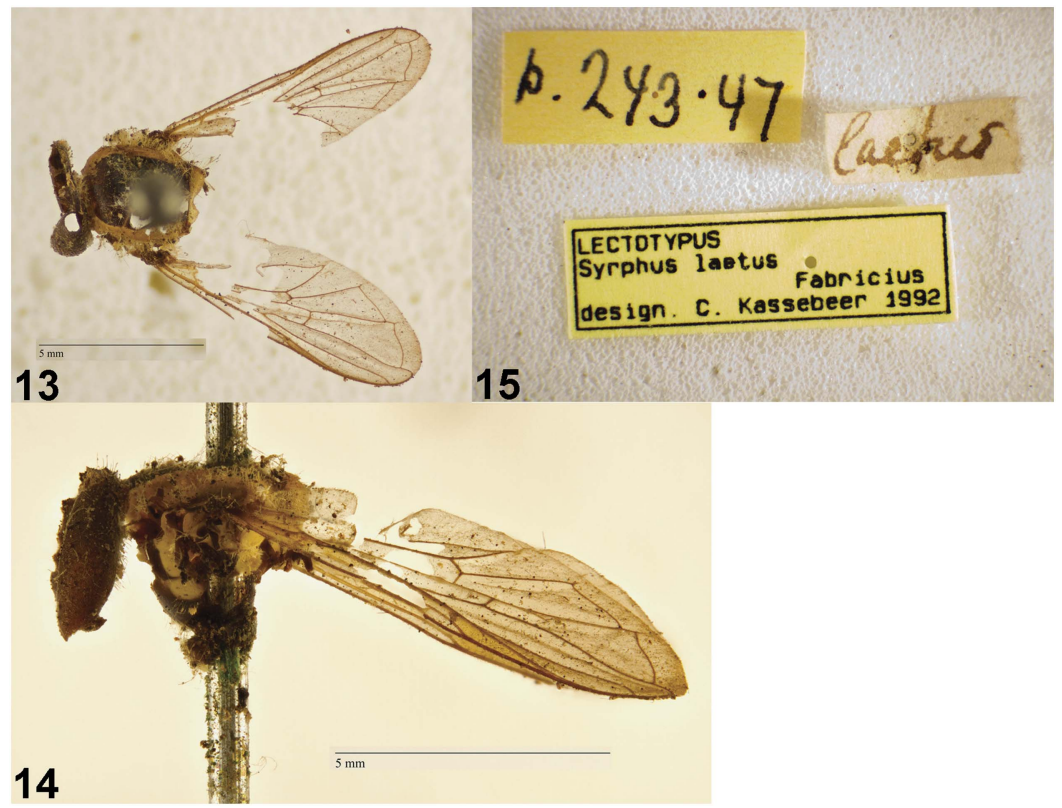

Figs. 16-18. Lasiophthicus novus (=Xanthogramma novum), lectotype. 16, dorsal view; 17, lateral view; 18, labels.
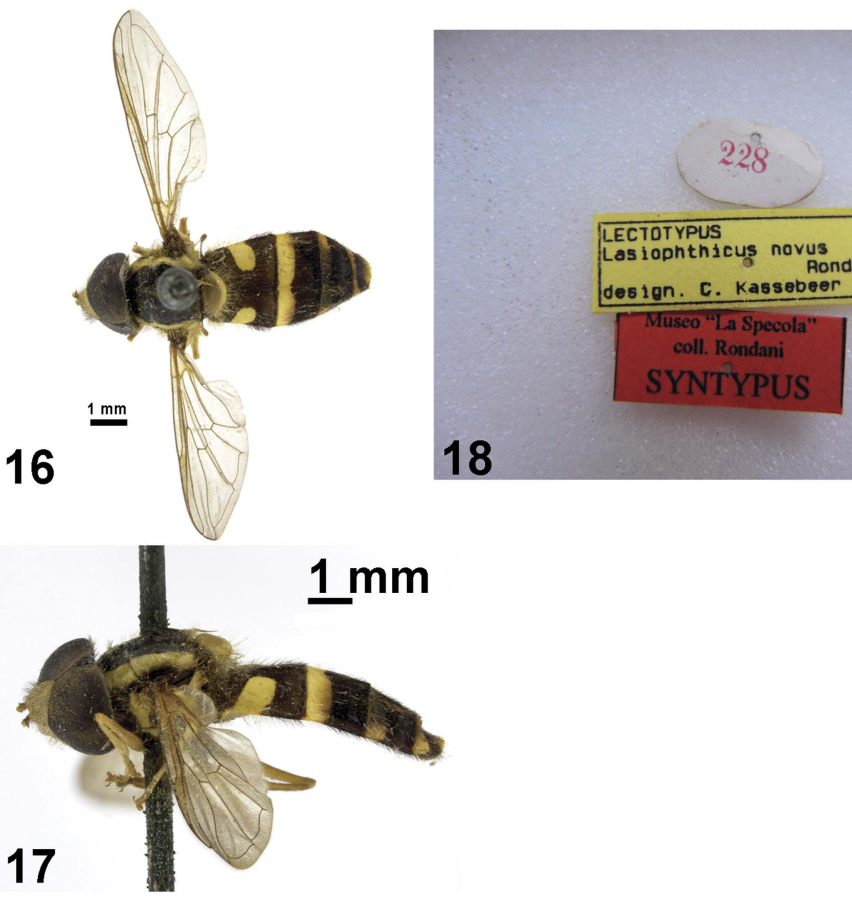

18 
designation was never published. We confirm Kassebeer's identification and herein formally designate this specimen as lectotype in order to fix identity of the species. This specimen belongs to the type series of $X$. laetum designated by Fabricius (1794).

Photographs (dorsal and lateral views) were also examined of the lectotype of $X$. novum. The lectotype of $X$. novum labelled by Kassebeer in LSF was never published. We confirm Kassebeer's identification and herein formally designate this specimen as lectotype in order to fix identity of the species. This specimen belongs to the type series of $X$. novum designated by Rondani (1857).

Distribution. From northern Germany south to southwestern France (Pyrenées-Atlantiques); from Belgium eastwards through central and southern Europe (Italy, former Yugoslavia) to Romania and European parts of Russia (Speight 2017).

Natural history. Adult fly from March to September. The larvae are undescribed (Speight 2017).

\section{Xanthogramma marginale (Loew, 1854)}

Doros marginale Loew, 1854: 18.

Xanthogramma morenae Strobl, 1899: 144. Junior synonym.

Material examined. Spain: 3o, Grazalema, Cadiz, 14.vi.2014, $36.757^{\circ} \mathrm{N}, 5.365^{\circ} \mathrm{W}$, Vujić (FSUNS).

Remarks. A female specimen of $X$. marginale labelled as "neotype" was examined from highresolution photographs of the head, thorax, and abdomen (dorsal and lateral views). Label data: "Andalusia" (handwritten)/“3773"/"marginalis Loew" (handwritten)/“Zool.Mus.Berlin"/"NEOTYPUS Doros marginalis Loew, design. C. Kassebeer 1992" [yellow label] (ZMHB). The designation of this specimen as neotype was never published. According to the International Commission on Zoological Nomenclature (1999) a neotype is validly designated when there is an exceptional need to fix a species concept in the framework of a complex taxonomic problem. The concept of $X$. marginale is not in question, as it is clearly different to all other European species (see diagnostic characters in the key provided in the present paper). Thus, a neotype designation is unnecesary at this moment and the specimen labelled by C. Kassebeer is confirmed to not have any neotype status. The holotype of Xanthogramma morenae (which was originally described as a variety of $X$. marginale) was examined by A. Vujić in NMBA. Label data: "Xanth. marginale Lw. var. Morenae m. Span: Cardenas Strobl ơ".

Distribution. Portugal, central and southern Spain, southern France, Italy and North Africa (Morocco, Algeria) (Speight 2017).

Natural history. Adults fly from April to mid of June. The larvae are undescribed (Speight 2017).

\section{Xanthogramma pedissequum (Harris, 1776)}

Musca pedissequus Harris, 1776: 61.

Syrphus ornatus Meigen, 1822: 298. Junior synonym.

Syrphus pulchrum Meigen, 1835: 69. Junior synonym.

Doros decoratum Zetterstedt, 1843: 694. Junior synonym.

Xanthogramma bilobatum Szilády, 1940: 64. 709 Junior synonym.

Xanthogramma flavifrons Szilády, 1940: 64. Junior synonym.

Xanthogramma nigripes Szilády, 1940: 64. Junior synonym.

Xanthogramma nobilitatum Frey, 1946: 162. Junior synonym.

Xanthogramma flavipleura Coe, 1957: 62. Junior synonym.

Material examined. Serbia: $2{ }^{\star}$, Pašnjaci velike droplje, 7.vi.2016, $45.925^{\circ} \mathrm{N} 20.298^{\circ} \mathrm{E}$, Tot, Nedeljković, and Markov (MS125, MS126) (FSUNS); $1{ }^{\star}$, Slano Kopovo, 6.vii.2013, 45.631 ${ }^{\circ} \mathrm{N}$, $20.196^{\circ} \mathrm{E}$, Stepanov (MS63) (FSUNS).

Remarks. The holotype of Xanthogramma pedissequum is lost (Pape and Thompson 2013a). We examined one male and one female from Bristol, United Kingdom - near the type locality collected by E.A. Fonseca (NHM). The lectotype of $X$. ornatum was examined with high-resolution photographs of the dorsal and lateral habitus of the specimen. The lectotype (here designated in order to fix identity of the species) is labelled as follows: "LECTOTYPE"/"S. ornatus o" (hand written)/"14S1 40" (handwritten)/ 
"MNHN Paris ED4027". We have searched for the type specimen of X. pulchum (Meigen, 1835) in the MNHN and NHMW collection, but we could not find it.

The lectotype of Xanthogramma decoratum (Zetterstedt, 1843) was examined with highresolution photographs of the dorsal and lateral habitus of the specimen (MZLU). The lectotype (here designated in order to fix identity of the species) is labelled as follows: "D. decoratum. ․ Scan." (handwritten)/ "Lectotypus Doros decoratum Zetterstedt design. C. Kassebeer 1992 / 1992 509" (blue label) / "MZLU Type no. 5714:1" (MZLU) (Figs. 19-21). The lectotype of $X$. decoratum labelled by Kassebeer was never published. We confirm Kassebeer's identification and herein formally designate this specimen as lectotype in order to fix identity of the species. This specimen belongs to the type series of $X$. decoratum designated by Zetterstedt (1843).

The type series of Xanthogramma bilobatum Szilády, 1940, Xanthogramma flavifrons Szilády, 1940, and Xanthogramma nigripes Szilády, 1940 were destroyed in a fire (Soltész Zoltán, HNHM, personal communication). The lectotype and paralectotype (one male and one female, respectively) of Xanthogramma nobilitatum (described originally as a variety of $X$. ornatum) were examined with high-resolution photographs of the dorsal and lateral habitus of the specimen (MZH) (Figs. 33-34). We designate the male as lectotype (here designated) in order to fix identity of the species. This specimen belongs to the type series of $X$. nobilitatum designated by Frey (1946).

The type of Xanthogramma flavipleura Coe, 1957 is lost (N. Wyatt, personal communication). After the examination of the type specimens of all taxa considered as synonyms of $X$. pedissequum, we confirm their status as synonyms.

Distribution. Uncertain, due to confusion with both $X$. dives and $X$. stackelbergi. Known from United Kingdom and European Atlantic seaboard countries south to southern France and into central Europe to the Alps (France, Switzerland) (Speight 2017).

Natural history. Adults fly from May to September, with a peak in July. The larvae are predators of root aphids tended by Lasius Fabricius, 1804 (Hymenoptera: Formicidae) (Speight 2017).

\section{Xanthogramma pilosum Nedeljković, Ricarte, and Vujić, new species}

Figs. 3-5, 11, 22, 24, 32.

Type material. HOLOTYPE: $\widehat{\jmath}$, Greece: 788 Lesvos, Plomari, Agios Issidoros, 13.iv.2011, 789 Vujić and Radenković, $38.971^{\circ} \mathrm{N}, 26.387^{\circ} \mathrm{E}, \quad 790$

Figs. 19-21. Doros decoratus (=Xanthogramma decoratum), lectotype. 19, dorsal view; 20, lateral view; 21, labels.

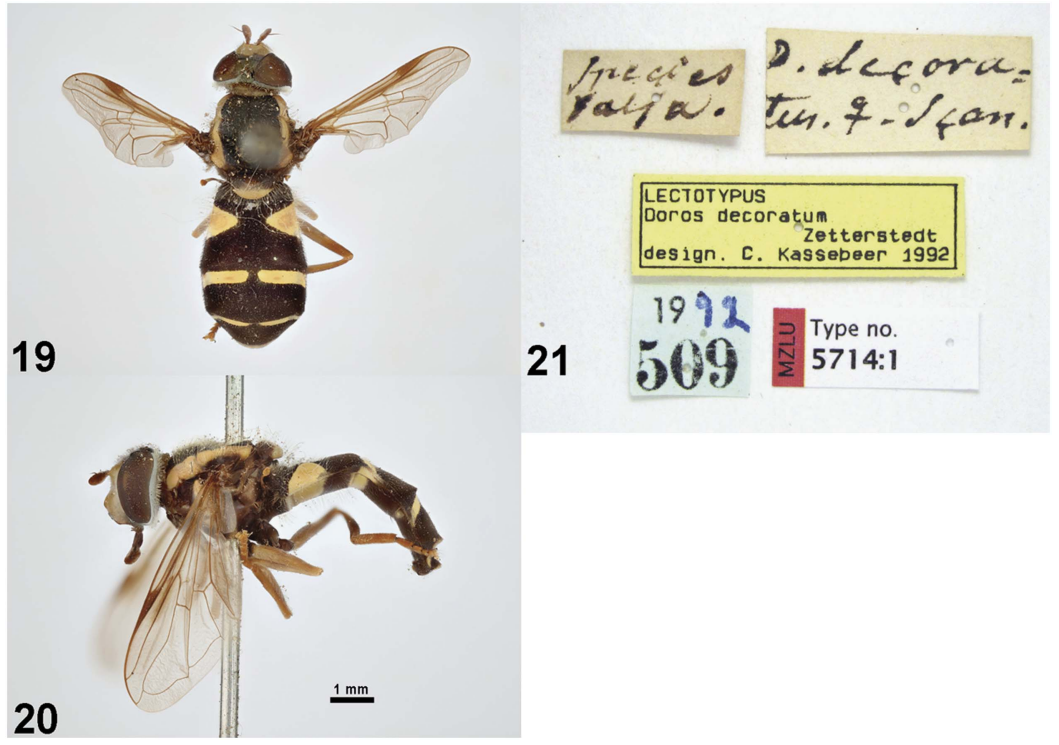


Fig. 22. Xanthogramma pilosum male holotype, head, lateral view.

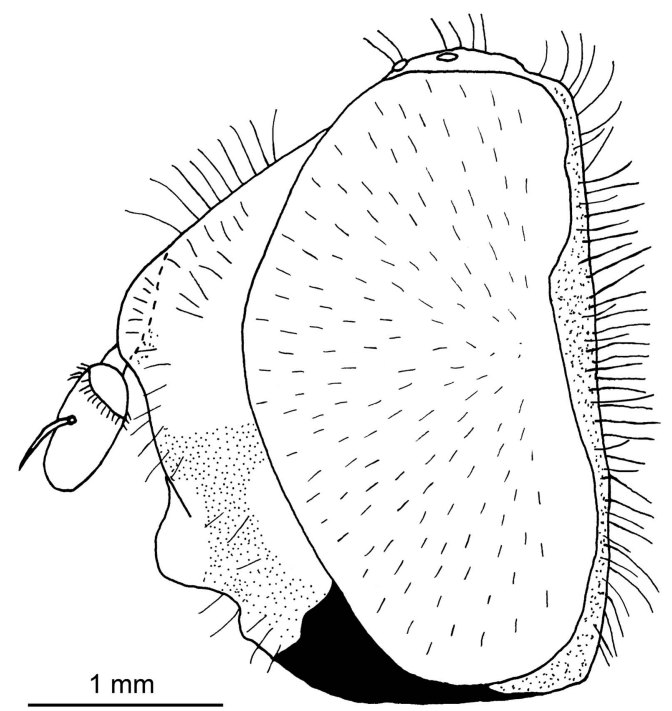

$\mathrm{R}_{1}$ with brown pigment; anterior and apical part of cell $\mathrm{R}_{2+3}$ with brown pigment.

Xanthogramma pilosum can be separated from Xanthogramma laetum (Fabricius, 1794) by the colour of the gena laterally, which is black in $X$. pilosum (Fig. 22) and mainly yellow in $X$. laetum (in some specimens partly black) (Table 2). Other differences separating these two species are the colour of the proepimeron in males, which is yellow in X. pilosum (Fig. 5) and black in X. laetum (Fig. 6). Pile on the frontal triangle and face are mainly black in $X$. laetum, but yellow in $X$. pilosum. Wing cells $\mathrm{R}_{1}, \mathrm{C}$, and $\mathrm{R}_{2+3}$ have brown pigment in X. pilosum (Fig. 24), while yellow in $X$. laetum (Fig. 23).

Description. Male (Figs. 3, 5, 11, 22, 32). Length $=9.2 \mathrm{~mm}$; Wing length $=8.5 \mathrm{~mm}$. Head (Fig. 22). Eye conspicuously pilose (longest pile about $1.1 \times$ longer than diameter of posterior ocelli), with bare areas near eye contiguity and near posterior eye margin; eye pile straight and yellow, denser and longer dorsally; vertical triangle black with black pollinosity and yellow pile; ocellar triangle nearly isosceles; occiput grey pollinose along eye margin, with long, yellow pile; frontal triangle yellow with yellow pile dorsally and some short, black pile ventrally (near lunule); lunule transparent black; antenna yellow, scape and pedicel with short yellow pile; basoflagellomere oval, basoflagellomere at the level of the arista base $=1.25 \mathrm{~mm}$; arista with short, sparse pile; face yellow with yellow pile; lateral parts of gena black, median part of gena yellow with yellow pile. Thorax (Fig. 5). Scutum black with two white pollinose vittae extending for anterior two-thirds of scutum length, scutum with long yellow pile; notopleuron yellow, at most narrowly black near anterior anepisternum; proepimeron with small yellow macula; posterior anepisternum with yellow macula on posterior part;

Figs. 23-24. Xanthogramma species, right wing, dorsal view. 23, Xanthogramma laetum; 24, Xanthogramma. pilosum, holotype.
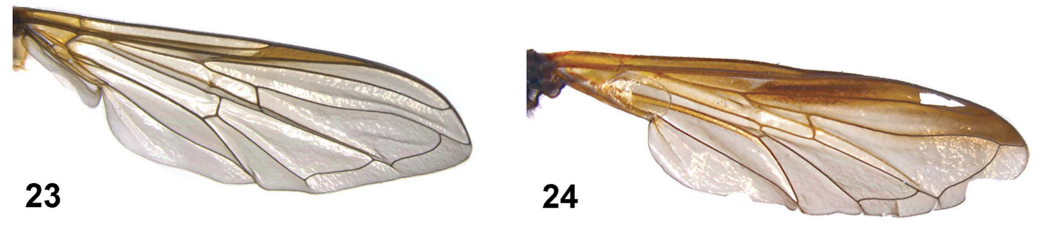
Table 2. Diagnostic morphological differences between Xanthogramma laetum and Xanthogramma pilosum.

\begin{tabular}{|c|c|c|}
\hline Character & X. laetum & X. pilosum \\
\hline \multicolumn{3}{|l|}{ Males and females } \\
\hline Eye pile & $\begin{array}{l}\text { Dense, long (length about } 1 \mathrm{~mm} \text { ), } \\
\text { same length in dorsal and ventral } \\
\text { parts of eye (Fig. 25) }\end{array}$ & $\begin{array}{l}\text { Sparse, shorter (length about } 0.6 \mathrm{~mm} \text { ), } \\
\text { denser and longer dorsally } \\
\text { (Fig. 22, 26) }\end{array}$ \\
\hline Face & Narrow $(11-13 \mathrm{~mm})$ & Broad (17-18 mm) \\
\hline Antennae & Brown, arista dark brown to black & Dark yellow, arista brown \\
\hline Wing cells $C, R_{1}$ and $R_{2+3}$ & Yellow pigment (Fig. 23) & Dark brown pigment (Fig. 24) \\
\hline Mesonotum & $\begin{array}{l}\text { With dense, long, yellow pile } \\
\text { (Fig. 29) }\end{array}$ & $\begin{array}{l}\text { With sparse, long and short, yellow } \\
\text { pile intermixed (Fig. 30) }\end{array}$ \\
\hline Colour of pile on femora & Black & Yellow \\
\hline Colour of femora & Black in the basal parts & Entirely dark yellow \\
\hline Shape of maculae on tergum 2 & Rectangular (Fig. 10) & Triangular (Figs. 3, 11) \\
\hline $\begin{array}{l}\text { Maculae on tergum } 3 \text { and } \\
\text { tergum } 4\end{array}$ & $\begin{array}{l}\text { Variable, connected in medial } \\
\text { part of terga or completely separated } \\
\text { (Fig. 10) }\end{array}$ & $\begin{array}{l}\text { Interrupted in medial part of } \\
\text { terga (Fig. 5) }\end{array}$ \\
\hline \multicolumn{3}{|l|}{ Males } \\
\hline Proepimeron & Black (Fig. 6) & With yellow macula (Fig. 5) \\
\hline
\end{tabular}

Figs. 25-26. Xanthogramma species, male, head, anterolateral view. 25, Xanthogramma laetum; 26, Xanthogramma pilosum, holotype.

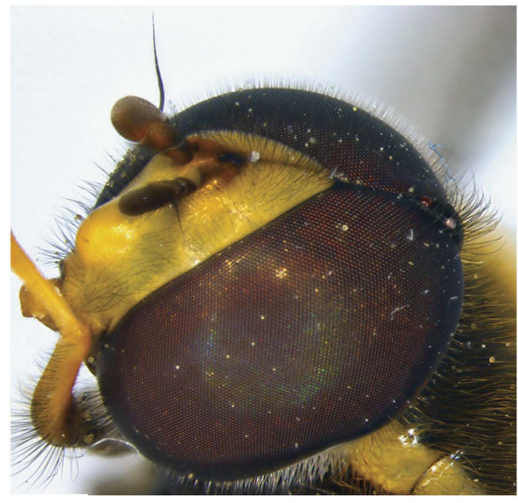

25 katepisternum with faint yellow macula; metaepisternum with yellow macula; scutellum transparent black in anterior part, clearly black at lateral corners and yellow in posterior part, with long, yellow pile; all legs yellow with yellow pile; wing membrane entirely microtrichose; wing cell $R_{1}$ and anterior part of cell $R_{2+3}$ with brown pigment; stigma dark brown to black. Abdomen (Figs. 3, 11). Shiny black with short, black pile, except tergum 1, anterior part of tergum 2, and yellow fasciae on terga with yellow pile; yellow fasciae reaching lateral margins of terga; sternum

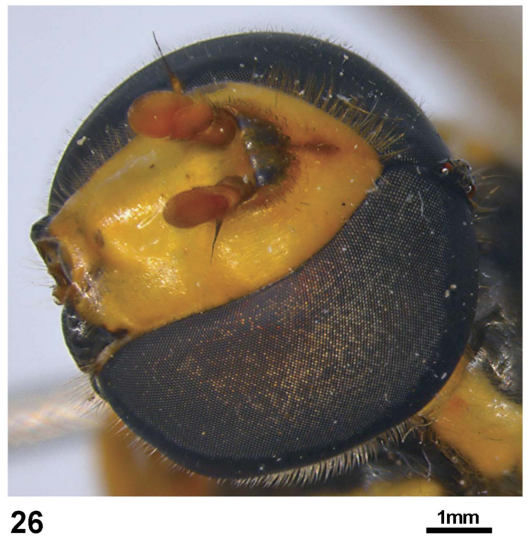

1 completely black, covered with long, yellow pile; sterna 2-4 black with yellow fascia on anterior margin, fasciae reaching lateral margins; sternum 2 with long, yellow pile; sterna 3 and 4 with yellow pile anteriorly (including fasciae) and black pile posteriorly. Sterna 2-4 completely surrounded by membrane. Male genitalia (Fig. 32). Surstylus triangular with rounded apex. Hypandrium $2.5 \times$ longer than wide.

Female (Fig. 4). Length $=12 \mathrm{~mm}$. Similar to male except for following characters: face yellow with yellow pile; black vitta extending from 
Figs. 27-30. Xanthogramma species, male, mesonotum, lateral view. 27, Xanthogramma aeginae, holotype; 28, Xanthogramma citrofasciatum; 29, Xanthogramma laetum; 30, Xanthogramma pilosum, holotype.

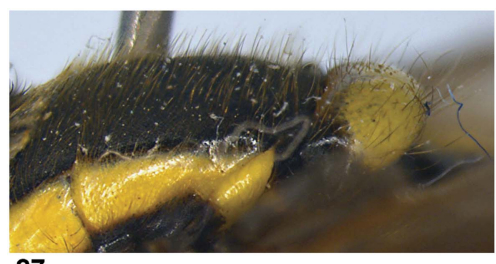

27

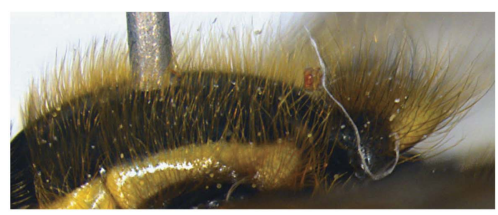

29

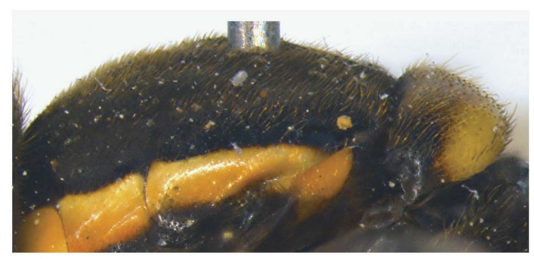

28

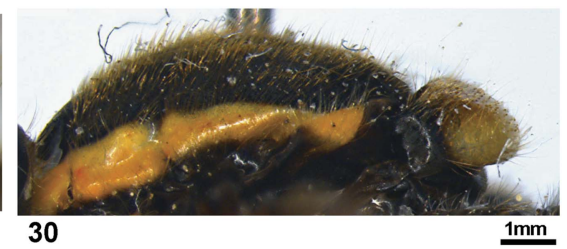

Figs. 31-32. Xanthogramma species, male genitalia, lateral view. 31, Xanthogramma aeginae, holotype; 32, Xanthogramma pilosum, holotype.

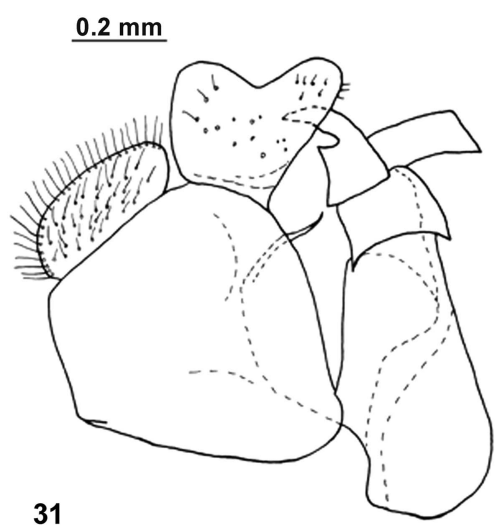

ocellar triangle to lunule with yellow and black pile intermixed; ocellar triangle black with long, yellow pile.

Etymology. The specific epithet "pilosum" is derived from the Latin adjective pilosum meaning pilose, referring to the pilose eyes of this species.

Distribution and habitat (Fig. 38). Greece, both mainland (Rhodopes Mountains in the Thrace region) and insular (Lesvos Island). This species inhabits Mediterranean forest and shrub regions.

Natural history. Adults fly from mid to end of April. Larvae are unknown.

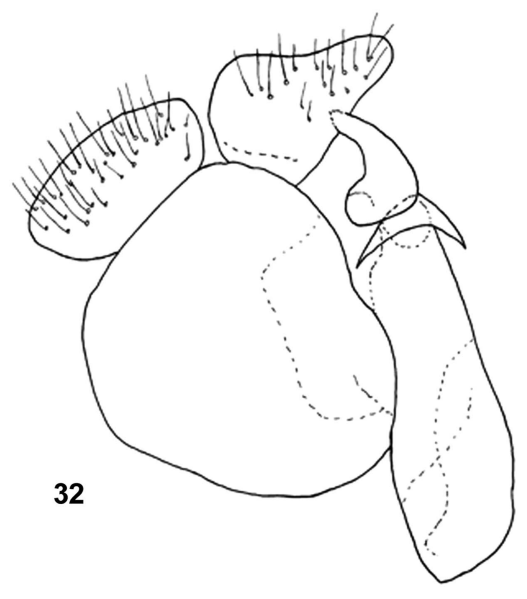

\section{Xanthogramma stackelbergi Violovitsh, 1975}

Xanthogramma stackelbergi Violovitsh, 1975: 99.

886

Material examined. Greece: 20 , Peloponnese, Karyes, $25 \mathrm{~km} \mathrm{~N}$ from Sparta, 22.v.2016, 37.304 ${ }^{\circ} \mathrm{N}$ $22.421^{\circ} \mathrm{E}$, Vujić, Nedeljković, Ačanski, Likov, and Miličić (MS142, MS143) (FSUNS); Serbia: 19, Fruška gora, Papratski Do, 10.viii.2013, $45.137^{\circ} \mathrm{N}, \quad 19.673^{\circ} \mathrm{E}, \quad$ Nedeljković $(\mathrm{MS} 147)$ (FSUNS); 10, Malinik, Manastirište, 22.vi.2012, $44.019^{\circ} \mathrm{N} 21.960^{\circ} \mathrm{E}$, Vujić (MS58) (FSUNS); 1 \%, Đerdap, Donji Milanovac, 7.v.2010, $44.460^{\circ} \mathrm{N}$ $22.155^{\circ} \mathrm{E}$, Vujić (MS45) (FSUNS). 
Remarks. The holotype of X. stackelbergi was examined with high-resolution photographs of the dorsal and lateral habitus of the specimen (ZISP).

Distribution. Uncertain, due to confusion between $X$. dives and $X$. pedissequum. Known from Norway, Sweden, Finland, parts of
European Russia, United Kingdom, Denmark, The Netherlands, southern Germany, Switzerland, France, Italy (Speight 2017), and Spain (Ricarte and Marcos García 2017).

Natural history. Adults fly from mid-May to midAugust. Larvae are not described (Speight 2017).

\section{Key to European species of Xanthogramma}

Adapted from Speight and Sommaggio (2010)

1. Tergum 2 wider than long; alula entirely covered in microtrichia $\ldots \ldots \ldots \ldots \ldots \ldots \ldots \ldots \ldots \ldots \ldots \ldots \ldots$ Tergum 2 longer than wide; alula with bare area $\ldots \ldots \ldots \ldots \ldots \ldots \ldots$. marginale (Loew, 1854)

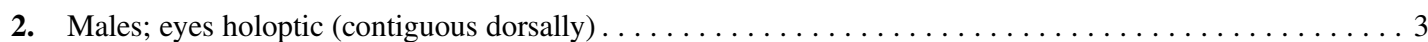

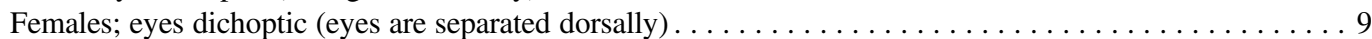

3. Eye pile very sparse and, at most, as long as the diameter of the anterior ocellus; terga 2-4 each with a pair of

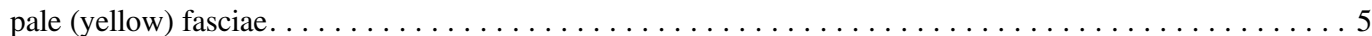

- Eye pile dense, longer than the diameter of the anterior ocellus (two times longer or more; terga 2-4 each with a

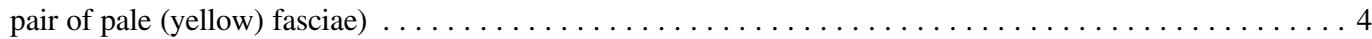

4. Eye pile dense, consistently long (about $1 \mathrm{~mm}$ ) all over the eye; wing cells $C, R_{1}$ and $R_{2+3}$ with yellow pigment; proepimeron entirely black; face narrow $(11-13 \mathrm{~mm})$; tergum 2 with rectangular maculae; tergum 3 with a pair of pale maculae in the medial part of tergum that appears as a yellow fascia (in some specimens, tergum 3 with a pair of yellow maculae not united medially) ................... laetum (Fabricius, 1794)

- Eye pile shorter (about $0.6 \mathrm{~mm}$ ), denser and longer on the dorsal part of eye; wing cells $C, R_{1}$ and $R_{2+3}$ with dark brown pigment; proepimeron with a yellow macula; face broad $(17-18 \mathrm{~mm})$; tergum 2 with triangular maculae; tergum 3 with a pair of yellow fasciae interrupted in the medial part of tergum $\ldots \ldots \ldots \ldots \ldots \ldots \ldots \ldots \ldots \ldots$. pilosum Nedeljković, Ricarte, and Vujić, new species

5. Pale maculae on tergum 21.5 times as wide as long, well separated from the base of the tergite; all legs entirely

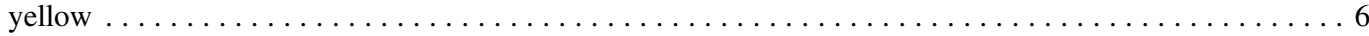
Pale maculae on tergum 2 at most 1.25 times as wide as long, almost reaching the base of the tergite laterally; metafemora black in the apical fourth.

6. Proepimeron black; katepisternum mainly black, especially with faint yellow macula; notopleuron black ventrally $\ldots \ldots \ldots \ldots \ldots \ldots \ldots \ldots \ldots \ldots \ldots \ldots \ldots \ldots \ldots \ldots \ldots \ldots \ldots \ldots \ldots \ldots$ citrofasciatum (De Geer, 1776) Proepimeron with a yellow macula ventrally; katepist $\mathrm{n}$ with a yellow macula; notopleuron yellow, at most narrowly black near the anterior anepisternum ...X. nae Ricarte, Nedeljković, and Vujić, new species

7. Lateral parts of thorax with $1-2$ yellow maculae $\ldots \ldots \ldots \ldots \ldots \ldots \ldots$. pedissequum (Harris, 1776) Lateral parts of thorax with more than two yellow maculae $\ldots \ldots \ldots \ldots \ldots \ldots \ldots \ldots \ldots$

8. Wing cells $R_{1}$ and $R_{2+3}$ with a black macula in the apical part; medial extremity of yellow maculae on tergum 2 usually pointed (fig. 1a-b: Speight and Sommaggio 2010); anterior margin of black vitta across sternite 2 straight or with a low, more-or-less rounded median projection (fig. 1e-f: Speight and Sommaggio 2010) . . .

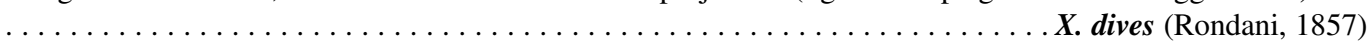

- Wing cells $R_{1}$ and $R_{2+3}$ hyaline in the apical; inner extremity of yellow maculae on tergum 2 very rounded (Fig. 1c-d: Speight and Sommaggio 2010); anterior margin of the black vitta across sternum 2 with a pointed, median extension (fig. 1g-h: Speight and Sommaggio 2010) . . . . . . . . . . X. stackelbergi Violovitsh, 1975

9. Eye pile very sparse, shorter than the diameter of the anterior ocellus $\ldots \ldots \ldots \ldots \ldots \ldots \ldots \ldots \ldots 11$

Eye pile longer than the diameter of the anterior ocellus $\ldots \ldots \ldots \ldots \ldots \ldots \ldots \ldots \ldots \ldots \ldots \ldots \ldots \ldots \ldots \ldots$ 
10. Tergum 2 with two rectangular yellow maculae; tergum 3 and tergum 4 each with a transverse yellow fascia

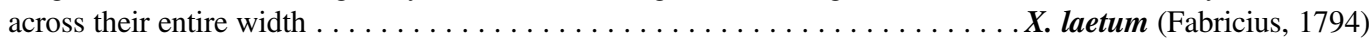
Tergum 2 with two triangular yellow maculae; tergum 3 and tergum 4 each with a pair of yellow fasciae not reaching the medial part of terga. ........... . pilosum Nedeljković, Ricarte, and Vujić, new species

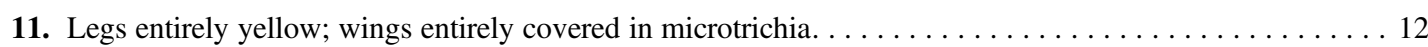

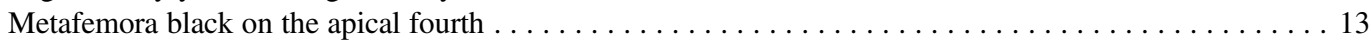

12. Proepimeron entirely black; notopleuron black ventrally.......... X. citrofasciatum (De Geer, 1776) Proepimeron with yellow macula; notopleuron yellow, at most narrowly black near the anterior

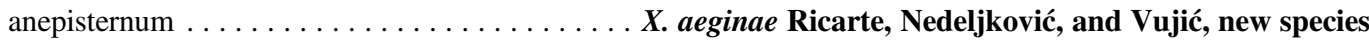

13. Thorax with $1-2$ yellow maculae laterally $\ldots \ldots \ldots \ldots \ldots \ldots \ldots \ldots \ldots$. pedissequum (Harris, 1776)

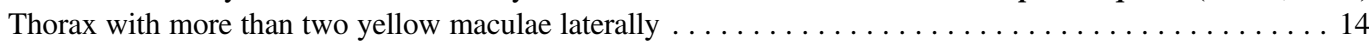

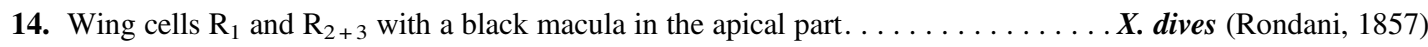
Wing cells $R_{1}$ and $R_{2+3}$ hyaline in the apical part $\ldots \ldots \ldots \ldots \ldots \ldots$. stackelbergi Violovitsh, 1975

\section{Molecular analyses of Xanthogramma species}

A 700-base-pair fragment of the 3'-end of the COI gene was obtained for 41 specimens of Xanthogramma. ITS2 sequences varying in length from 351 base pairs to 372 base pairs were obtained for 49 specimens. The alignment of in-group ITS2 sequences resulted in a data set of 391 characters, while with the added outgroup sequence the alignment yielded 415 characters when insertion/deletion events were considered. The length of ITS2 sequence of the outgroup taxa (Melanostoma mellinum) used in alignment was 390 base pairs. The final COI data set of the in-group taxa had 66 variable positions, 61 of which were parsimony informative. The ITS2 data set had 59 variable positions and 56 were parsimony informative.

COI and ITS2 sequences were analysed separately but also as a combined data set under the maximum parsimony approach. The parsimony analysis of ITS2 sequences resulted in four equally parsimonious trees with 223 steps of length (consistency index $=90$, retention index $=$ 91). The strict consensus tree (length $=225$ ) resolved the species $X$. laetum and $X$. marginale, as well as the two new species, $X$. pilosum and $X$. aeginae, as monophyletic clades. Xanthogramma aeginae clade and $X$. citrofasciatum were resolved in a polytomy with the sequences of $X$. dives and $X$. stackelbergi. Xanthogramma citrofasciatum clade has low bootstrap support value, with one sample outside the clade (MS103). Xanthogramma pedissequum was resolved as a paraphyletic, and the cluster $X$. dives, $X$. stackelbergi, $X$. citrofasciatum, and $X$. aeginae was nested
Figs. 33-34. Xanthogramma nobilitatum, lectotype. 33, dorsal view; 34, lateral view.

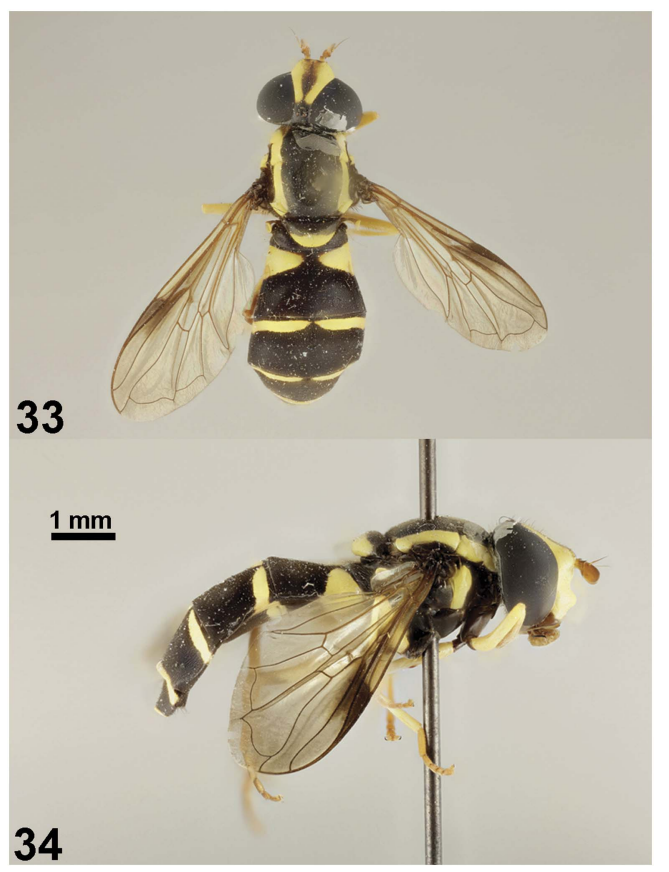

within it. In addition, Xanthogramma laetum was resolved as the sister species to remaining Xanthogramma species (Fig. 39).

The parsimony tree of COI sequences (length $=$ 130 steps, consistency index $=91$, retention index $=$ 96) resolved four clades, which corresponded to $X$. marginale, $X$. pilosum, $X$. citrofasciatum, and $X$. aeginae, as well as a clade that comprised sequences of three different species (X. pedissequum, $X$. dives, and $X$. stackelbergi). Within the last clade, $X$. pedissequum sequences form a nested clade with 
low bootstrap support. Xanthogramma citrofasciatum and $X$. aeginae were resolved as sister species. Xanthogramma laetum was not included in this analysis as we were not able to produce COI sequences for this species (Fig. 40).

Maximum parsimony analysis of the combined COI and ITS2 sequences resulted in two equally parsimonious trees (length $=354$ steps, consistency index $=90$, retention index $=94$ ). The topology of the strict consensus tree (length $=363$ ) was similar to that of COI tree (Fig. 41).

Figs. 35-37. Syrphus ornatus (=Xanthogramma ornatum), lectotype. 35, dorsal view; 36, lateral view; 37, labels.
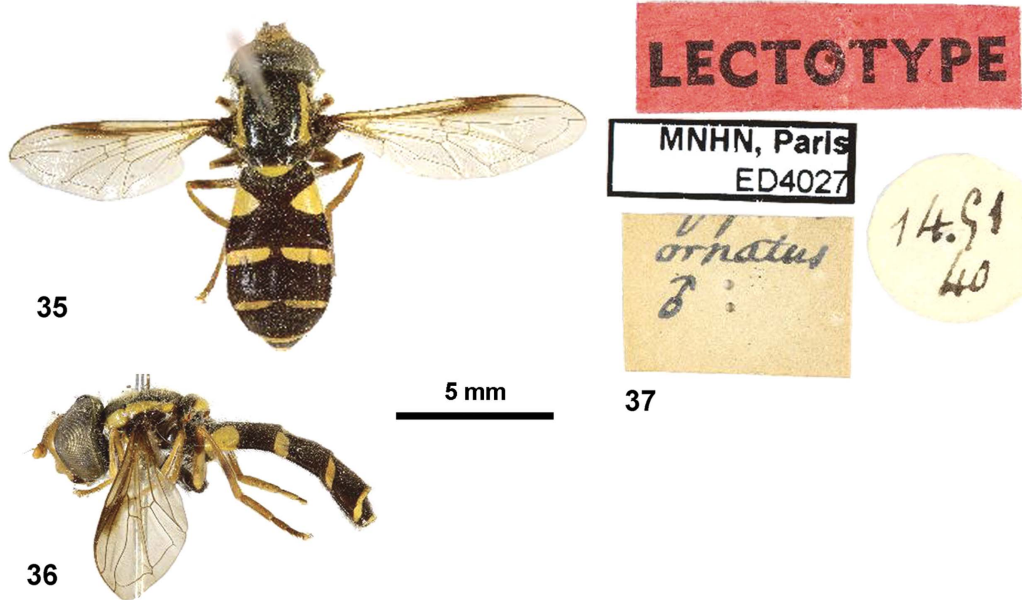

This study integrates information from different sources, including both morphological and molecular data, to establish species limits within the European Xanthogramma species. Species boundaries, first established according to adult morphological characters, were treated as hypotheses and tested using a parsimony analysis of COI and ITS2 sequences. The results of this analysis clearly confirmed the presence of two Xanthogramma species new

Fig. 38. Map of population sampling locations of the examined species.

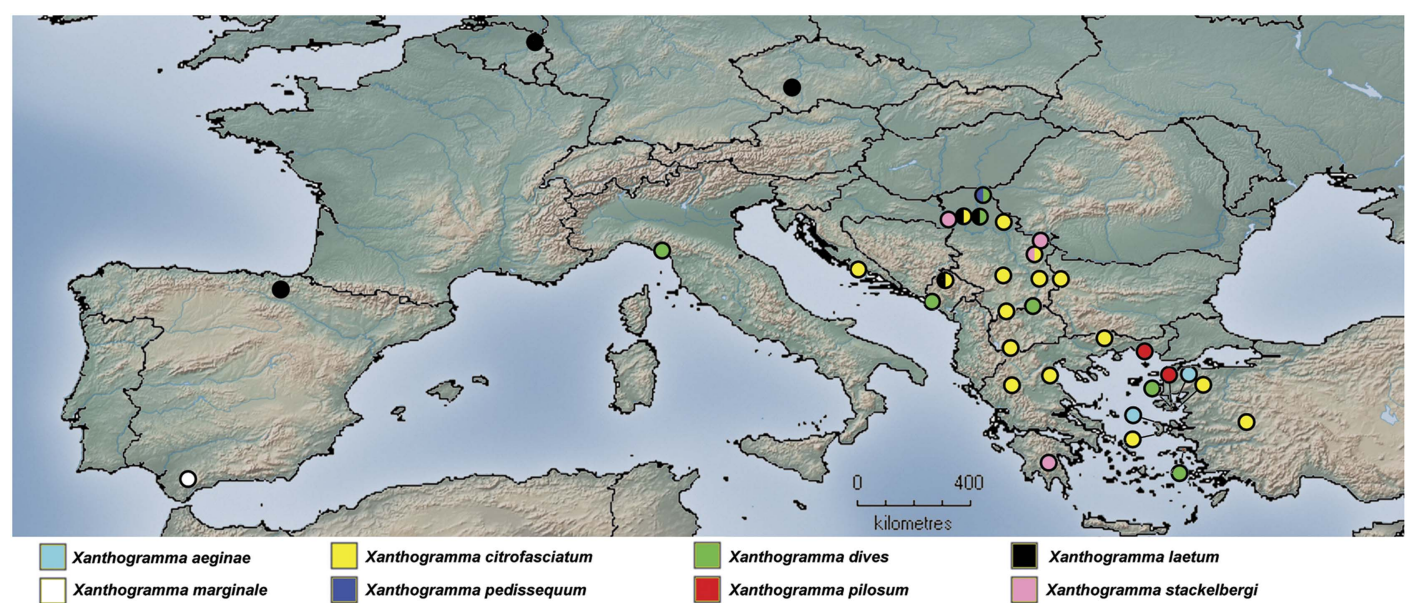


Fig. 39. ITS2 strict consensus tree of four equally parsimonious trees. Length $=225$ steps; consistency index $(\mathrm{ci})=89$; retention index $(\mathrm{RI})=90$. Bootstrap values higher than 50 are indicated near nodes. Filled circles indicate non-homoplasious changes and open circles homoplasious changes. aff., species affinis.

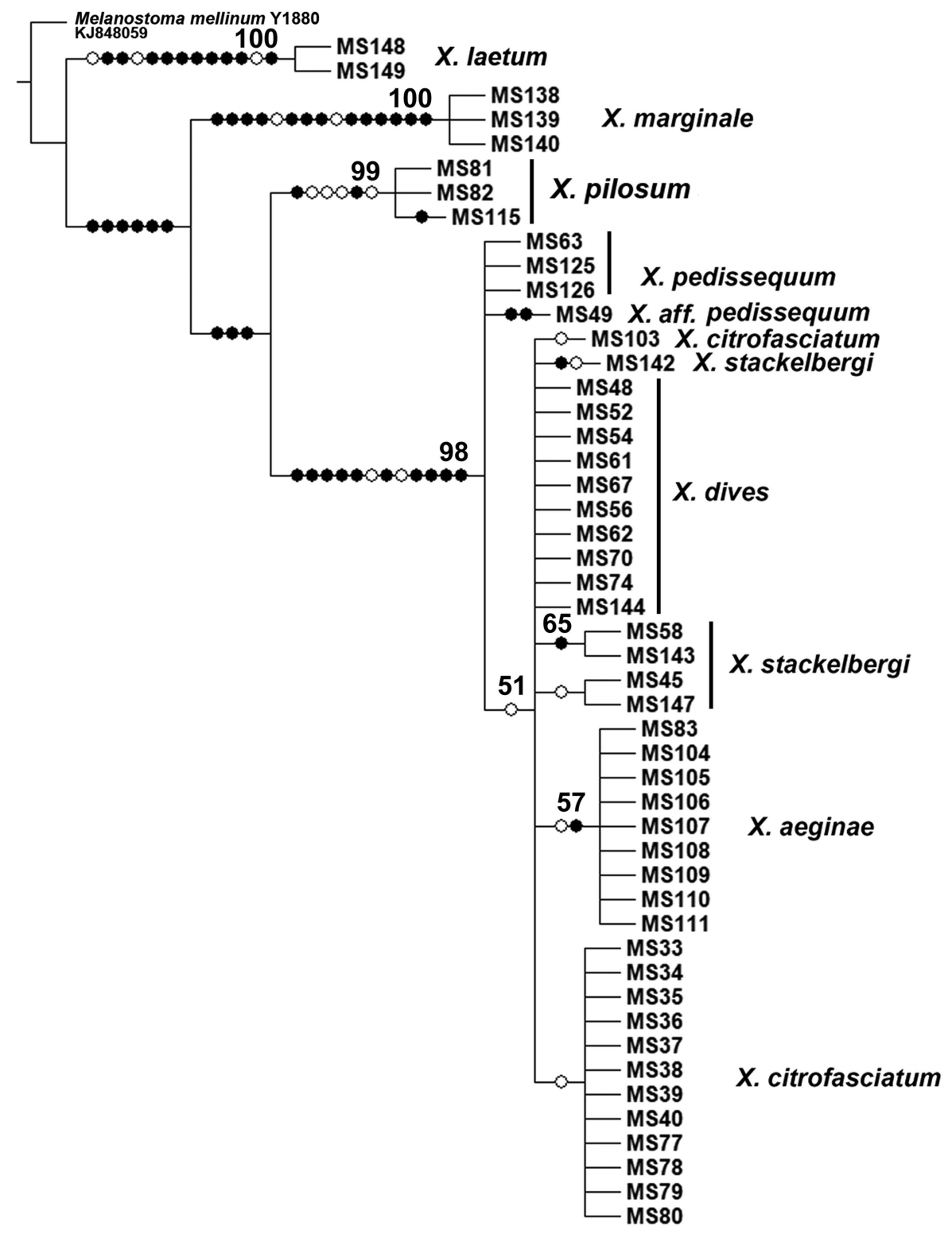

to science: $X$. aeginae and $X$. pilosum. In addition, the new data on the other six European species of Xanthogramma contribute to a greater understanding of the distribution and phenology of these species.

Xanthogramma aeginae can be distinguished from the similar $X$. citrofasciatum by the presence of a yellow macula on the proepimeron (Fig. 7), which is completely black in $X$. citrofasciatum (Fig. 8). The pile of the posterior anepisternum are all black in $X$. aeginae, but mainly yellow in $X$. citrofasciatum. Xanthogramma pilosum can be separated from the similar Xanthogramma laetum by the colour of the gena laterally, which is black in X. pilosum (Fig. 22) and mainly yellow in $X$. laetum. Other differences separating these two 
Fig. 40. COI tree based on maximum parsimony approach. Length $=130$ steps; consistency index $(\mathrm{ci})=91$; retention index $(\mathrm{RI})=96$. Bootstrap values higher than 50 are indicated near nodes. Filled circles represent non-homoplasious changes and open circles homoplasious changes.

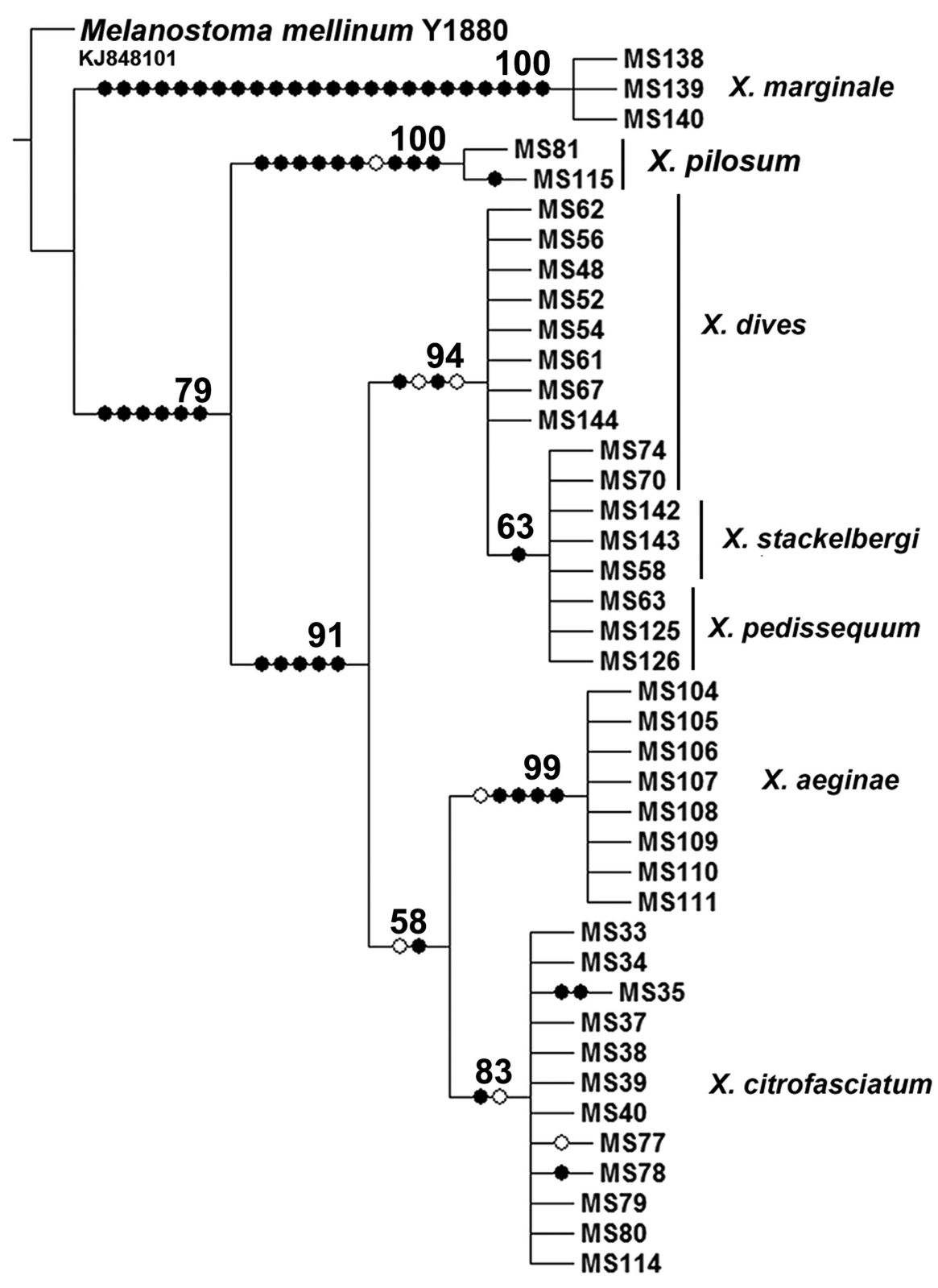

species are the colour of the proepimeron in males, which is yellow in X. pilosum (Fig. 5) and black in X. laetum (Fig. 6).

Xanthogramma pilosum and X. aeginae were confirmed as new species based on molecular data analyses. Both species form monophyletic clades on maximum-parsimony trees of COI,
ITS2 (Figs. 36-37), and combined 3'COI and ITS2 92 (Fig. 41). Xanthogramma aeginae is morphologi- 93 cally similar and closely related to X. citrofasciatum. 94 Xanthogramma pilosum is morphologically similar 95 to $X$. laetum from which differs based on ITS2 96 sequences. These two species form clearly separated 97 monophyletic clades on ITS2 tree (Fig. 39). 
Fig 41. Combined analysis of COI and ITS2 sequences. Strict consensus of two equally parsimonious trees. Length $=363$ steps; consistency index $=88$; retention index $=92$. Bootstrap values higher than 50 are indicated near nodes. Filled circles denote non-homoplasious changes and open circles homoplasious changes.

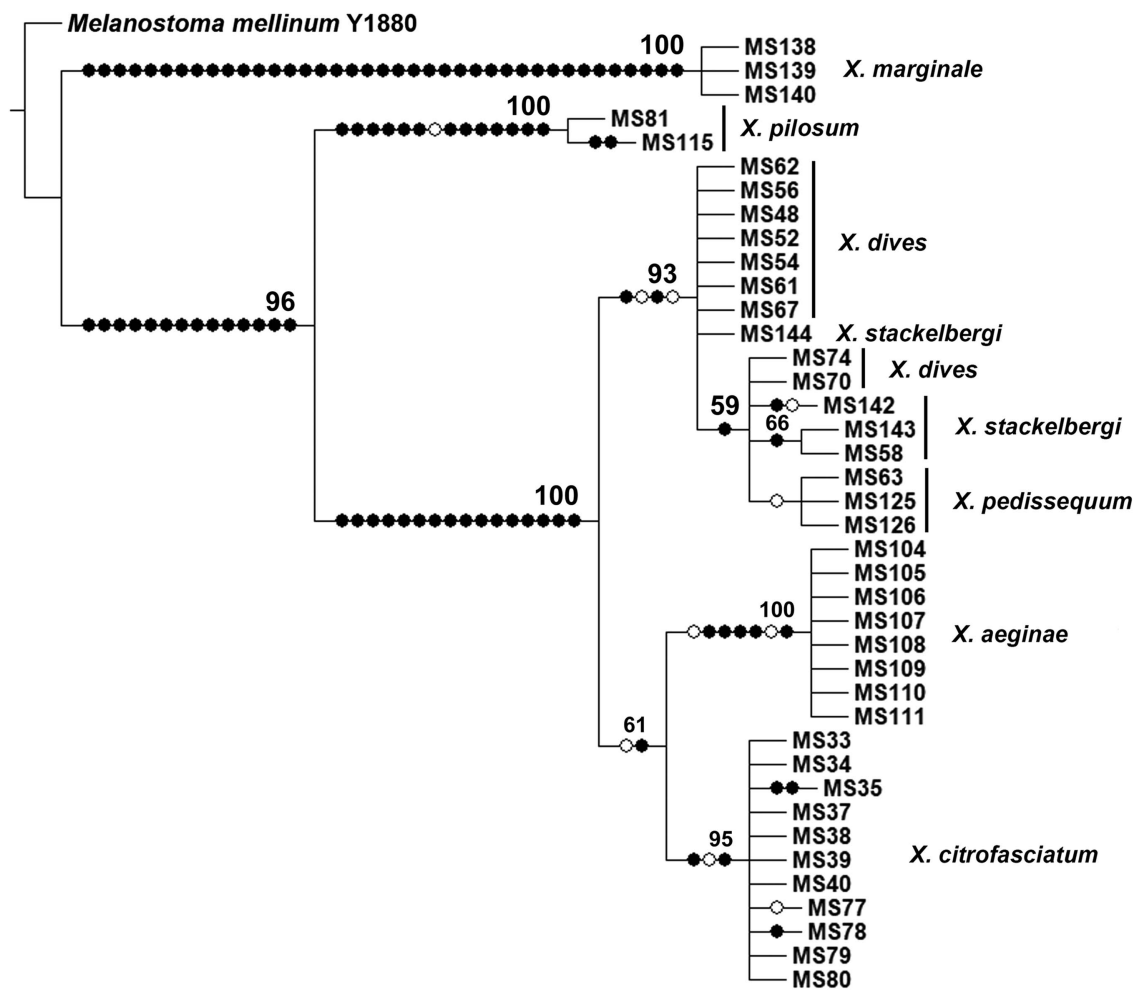

Regarding other Xanthogramma species, molecular markers failed to separate $X$. dives and $X$. stackelbergi, in accordance with the fact that many of the morphological characters used to identify them are variable (Speight and Sommaggio 2010). However, Xanthogramma pedissequum, which has the closest morphology to $X$. dives and $X$. stackelbergi, is resolved as separate species based on ITS2 sequences, even though these three species are indistinguishable based on COI sequences. In addition, a specimen of $X$. pedissequum (MS49) from Montenegro (Durmitor Mountain) differs from the other three specimens of the same species (MS63 - Serbia, Novi Bečej; MS125, MS126 - Serbia, Mokrin) by two non-homoplasious characters on ITS2 tree (Fig. 39). In addition, subtle morphological differences of this outlier (MS49) were detected in comparison with the other analysed $X$. pedissequum specimens. Thus, further studies are required to resolve the taxonomy of the $X$. pedissequum species group.
Southeastern Europe, which includes the Balkan Peninsula and Aegean Islands, is one of the most important regions of biodiversity within Europe. This diversity results from the fact that this peninsula serves as a crossroads for European, Mediterranean, and Asian faunas (CrnobrnjaIsailović 2007; Savić 2008; Poulakakis et al. 2015). For hoverflies, species diversity in the Balkan Peninsula is among the highest in Europe, with many endemic and relict species (Vujić et al. 2001), as well as cryptic taxa (Nedeljković et al. 2013, 2015; Popović et al. 2015; Vujić et al. 2013, 2015; Ačanski et al. 2016; Šašić et al. 2016). Our research confirms that the Balkan Peninsula and Aegean Islands are important reservoirs of hoverfly diversity in Europe.

\section{Acknowledgements}

The authors thank Dr. Theodora Petanidou (MAUA), Dr. Miroslav Barták (MB), Michael de Courcy Williams (MCDS), André Van Eck
121 
(AVE), and Wouter Van Steenis (WSB) for enabling access to part of the examined material. They thank Dr. Miguel Ángel Alonso Zarazaga (Museo Nacional de Ciencias Naturales, Madrid, Spain) and Neal Evenhuis (Bernice Pauahi Bishop Museum, Honolulu, Hawaii, United States of America) for nomenclatural advice. The authors also thank Dieter Doczkal (Germany) and Dr. Martin C.D. Speight (Ireland) for taxonomic advice. Thanks to Dr. Gunilla Ståhls (University of Helsinki, Finland) for advice on molecular analyses. Thanks to Dr. Nigel Wyatt (NHM, London, United Kingdom) for information about the Harris and De Geer type specimens and photographs of Xanthogramma pedissequum. Thanks to Dr. Luca Bartolozzi (LSF), Dr. Thomas Pape (ZMUC), Dr. Sven Marotzke (ZMHB), and Dr. Olga Ovtshinnikova (ZISP) for photographs of type specimens. Thanks to Dr. Petr Heřman (NMBA, Austria) for information about the Strobl type specimens. Thanks to André Van Eck and Wouter Van Steenis for providing fresh specimens of X. laetum. Thanks to the members of the Palynology Laboratory, University of Novi Sad (Serbia) for allowing the authors use their technological facilities. The authors thank Laura Likov (Novi Sad, Serbia) for helping in preparing the figures and for producing the map. Thanks to Tamara Tot for taxonomic advice. Authors are grateful to John O'Brien for English proofreading.

\section{Financial Support}

Financial support was provided by the Serbian Ministry of Education and Science (projects OI173002 and III43002), the Provincial Secretariat for Science and Technological Development (project "Genetic resources of agro-ecosystems in Vojvodina and sustainable agriculture"), the FP7 EU project, Innosense, and the H2020 project "ANTARES" (664387), Antonio Ricarte's position at the University of Alicante is funded by the Vicerrectorado de Investigación y Transferencia de Conocimiento).

\section{Supplementary material}

To view supplementary material for this article, please visit https://doi.org/10.4039/tce.2018.21

\section{References}

Ačanski, J., Vujić, A., Đan, M., Obreht Vidaković, D., Ståhls, G., and Radenković, S. 2016. Integrative taxonomy in defining species boundaries in Merodon avidus complex (Diptera: Syrphidae). European Journal of Taxonomy, 237: 1-25. http://dx.doi.org/ 10.5852/ejt.2016.237.

Andrić, A., Šikoparija, B., Obreht, D., Đan, M., Preradović, J., Radenković, S., et al. 2014. DNA barcoding applied: identifying the larva of Merodon avidus (Diptera: Syrphidae). Acta Entomologica Musei Nationalis Pragae, 54: 741-757.

Bartsch, H., Binkiewicz, E., Klintbjer, A., Rådén, A., and Nasibov, E. 2009. Blomflugor: Syrphinae. Nationalnyckelntill Sveriges frola och fauna, Artdatabanken. Sveriges lantbruksuniversitet, Uppsala, Sweden.

Beebe, N.W. and Saul, A. 1995. Discrimination of all members of the Anopheles punctulatus complex by polymerase chain reaction-restriction fragment length polymorphism analysis. The American Journal of Tropical Medicine and Hygiene, 53: 478-481.

Bezzi, M. and Stein, P. 1907. Cyclorrapha Aschiza. Cyclorrapha Schizophora: Schizometopa. In Katalog deb Paläarktischen Dipteren. Edited by T. Becker, M. Bezzi, and P. Stein. Dugonics-nyomda Részvénytársaság Szeged, Budapest, Hungary. Pp. 1-842.

Chen, H., Rangasamy, M., Tan, S.Y., Wang, H., and Siegfried, B.D. 2010. Evaluation of five methods for total DNA extraction from western corn rootworm beetles. Public Library of Science One, 5: e11963. https://doi.org/10.1371/journal.pone.0011963.

Chroni, A., Djan, M., Obreht Vidaković, D., Petanidou, T., and Vujić, A. 2017. Molecular species delimitation in the genus Eumerus (Diptera: Syrphidae). Bulletin of Entomological Research, 107: 126-138. https://doi.org/ 10.1017/S0007485316000729.

Coe, R.L. 1957. Some new Syrphidae (Diptera) from Yugoslavia. Proceedings of the Royal Entomological Society of London (B), 26: 60-62.

Coquillett, D.W. 1910. Corrections to my paper on the type-species of the North American genera of Diptera. The Canadian Entomologist, 42: 375-378.

Crnobrnja-Isailović, J. 2007. Cross-section of a refugium: genetic diversity of amphibian and reptile populations in the Balkans. In Phylogeography of southern European refugia. Edited by S. Weiss and N. Ferrand. Springer, Dordrecht, The Netherlands. Pp. 327-337.

De Geer, C. 1776. Memoires pour servir a l'histoire des insectes. Volume 6. P. Hesselberg, Stockholm, Sweden.

Dušek, J. and Láska, P. 1967. Versuch zum aufbau eines Naturlichen Systems mitteleuropaischer Arten der Unterfamilie Syrphinae (Diptera). Acta scientiarum naturalium Academiae Scientiarum Bohemicae, Brno, 1: 349-390.

Fabricius, J.C. 1794. Entomologia systematica emendata et aucta. Secundum classes, ordines, genera, species adjectis synonymis, locis, observationibus, descriptionibus. Volume 4. C.G. Proft, Copenhagen, Denmark. 
Frey, R. 1946. Übersicht der Gattungen der SyrphidenUnterfamilie Syrphinae (Syrphine + Bacchinae). Notulae Entomologicae, 25: 152-172.

Goloboff, P. 1999. NONA computer program. Version 2.0. Tucumac, Argentina [online]. Available from www.softpedia.com/get/Science-CAD/NONA. shtml [accessed 21 March 2018].

Goloboff, P.A., Farris, J.S., and Nixon, K.C. 2008. TNT, a free program for phylogenetic analysis. Cladistics, 24: 774-786. Available from www.lillo. org.ar/phylogeny/tnt [accessed 10 March 2018].

Grković, A., Vujić, A., Radenković, S, Chroni, A., and Petanidou, T. 2015. Diversity of the genus Eumerus Meigen (Diptera, Syrphidae) on the eastern Mediterranean islands with description of three new species. Annales de la Société entomologique de France (N.S.), 51: 361-373. http://dx.doi.org/ 10.1080/00379271.2016.1144483.

Haarto, A. and Ståhls, G. 2014. When mtDNA COI is misleading: congruent signal of ITS2 molecular marker and morphology for North European Melanostoma Schiner, 1860 (Diptera, Syrphidae). Zookeys, 431: 93134. https://doi.org/10.3897/zookeys.431.7207.

Hall, T.A. 1999. BioEdit: a user-friendly biological sequence alignment editor and analysis program for Windows 95/98/ NT. Nucleic Acids Symposia, 41: 95-98.

Harris, M. 1776. An exposition of English insects, with curious observations and remarks, wherein each insect is particulary described; its parts and properties considered; the different sexes distinguished, and the natural history faithfully related. The whole illustrated with copper plates, drawn, engraved and coloured, by the author. Privately published, London, United Kingdom.

Hölldobler, K. 1929. Über die Entwicklung der Schwierfleige Xanthogramma citrofasciatum im Neste von Lasius alienus und niger. Zoologischer Anzeiger, 82: 171-176.

International Commission on Zoological Nomenclature. 1999. International Code of Zoological Nomenclature, 4th edition. The International Trust for Zoological Nomenclature, London, United Kingdom. International Commission on Zoological Nomenclature. 2001. Opinion 1982 (case 3090). Musca arcuata Linnaeus, 1758 and $M$. festiva Linnaeus, 1758 (currently Chrysotoxum arcuatum and C. festivum) and $M$. citrofasciata De Geer, 1776 (currently Xanthogramma citrofasciatum) (Insecta: Diptera): specific names conserved by the designation of neotypes for $M$. arcuata and $M$. festiva. Bulletin of Zoological Nomenclature, 58: 241-242.

Katoh, K. and Standley, D.M. 2013. MAFFT multiple sequence alignment software version 7: improvements in performance and usability. Molecular Biology and Evolution, 30: 772-780. https://doi. org/10.1093/molbev/mst010.

Láska, P., Mazánek, L., and Bičík, V. 2013. Key to adults and larvae of the genera of European Syrphinae (Diptera, Syrphidae). Časopis Slezského Zemského Muzea (A), 62: 193-206.
Librado, P. and Rozas, J. 2009. DnaSP v5: A software for comprehensive analysis of DNA polymorphism data. Bioinformatics, 25: 1451-1452. https://doi.org/ 10.1093/bioinformatics/btp187.

Loew, H. 1854. Neue Beitrage zur Kenntniss der Dipteren. Zweiter Beitrag. Programm K. Realschule Meseritz, 1854: 1-24.

Marcos-García, M.A., Vujić, A., Ricarte, A., and Ståhls, G. 2011. Towards an integrated taxonomy of the Merodon equestris species complex (Diptera: Syrphidae) including description of a new species, with additional data on Iberian Merodon. The Canadian Entomologist, 143: 332-348. http://dx. doi.org/10.4039/n11-013.

McWilliam, H., Li, W., Uludag, M., Squizzato, S., Park, M.Y., Buso, N., et al. 2013. Analysis tool web services from the EMBL-EBI. Nucleic Acids Research, 41: W597-W600. https://doi.org/ 10.1093/nar/gkt376.

Meigen, J.W. 1822. Systematische Beschreibung der bekannten europäischen zweiflügeligen Insekten. Hamm, 3: X + 1-416.

Meigen, J.W. 1835. Neue Arten von Diptera aus der Umgegend von München, benannt und beschrieben von Meigen, aufgefunden von Dr. J. Waltl. In Faunus 2. Edited by J. Gistel. Lindauer'sche Verlagsbuchhaudlung, Munich, Germany. Pp. 66-72.

Mengual, X. 2012. The flower fly genus Citrogramma Vockeroth (Diptera: Syrphidae): illustrated revision with descriptions of new species. Zoological Journal of the Linnean Society, 164: 99-172. https://doi.org/ 10.1111/j.1096-3642.2011.00750.x..

Mengual, X., Ståhls, G., and Rojo, S. 2008. First phylogeny of predatory flower flies (Diptera, Syrphidae, Syrphinae) using mitochondrial COI and nuclear 28S rRNA genes: conflict and congruence with the current tribal classification. Cladistics, 24: 543-562. https://doi.org/10.1111/j.1096-0031.2008.00200.x.

Mik, J. 1897. Einige Bemerkungen zur DipterenFamilie der Syrphiden. Wiener Entomologische Zeitung, 16: 113-119.

Nedeljković, Z., Ačanski, J., Đan, M., ObrehtVidaković, D., Ricarte, A., and Vujić, A. 2015. An integrated approach to delimiting species borders in the genus Chrysotoxum Meigen, 1803 (Diptera: Syrphidae), with description of two new species. Contributions to Zoology, 84: 285-304.

Nedeljković, Z., Ačanski, J., Vujić, A., Obreht, D., Đan, M., Ståhls, G., and Radenković, S. 2013. Taxonomy of Chrysotoxum festivum Linnaeus, 1758 (Diptera: Syrphidae) - an integrative approach. Zoological Journal of the Linnean Society, 169: 84-102. https://doi.org/10.1111/zoj.12052.

Nixon, K.C. 1999. The parsimony ratchet, a new method for rapid parsimony analysis. Cladistics, 15: 407-414.

Nixon, K.C. 2008. ASADO, version 1.85 TNT-MrBayes Slaver version 2; mxram 200 (vl 5.30). Made available through the author (previously named WinClada, version 1.00 .08 (2002)). Available from www.diversity oflife.org/winclada [accessed 21 March 2018]. 
Pape, T. and Thompson, F.C. 2013a. Systema Dipterorum, version 1.5 [online]. Available from www. diptera.org [accessed 2 November 2016].

Pape, T. and Thompson, F.C. 2013b. Xanthogramma Schiner 1860. Systema Dipterorum, version 1.5 [online]. Available from www.diptera.org [accessed 27 November 2017].

Parks, D.H., Mankowski, T., Zangooei, S., Porter, M.S., Armanini, D.G., Baird, D.J., et al. 2013. GenGIS 2: geospatial analysis of traditional and genetic biodiversity, with new gradient algorithms and an extensible plugin framework. Public Library of Science One, 8: e69885. https://doi.org/10.1371/ journal.pone.0069885.

Peck, L.V. 1988. Syrphidae. In Catalogue of Palaearctic Diptera. Edited by A. Soos and L. Papp. Akademia Kiado, Budapest, Hungary. Pp. 1-327.

Popović, D., Ačanski, J., Djan, M., Obreht, D., Vujić, A., and Radenković, S. 2015. Sibling species delimitation and nomenclature of the Merodon avidus complex (Diptera: Syrphidae). European Journal of Entomology, 112: 790-809. https://doi.org/10.14411/eje.2015.100.

Poulakakis, N., Kapli, P., Lymberakis, P., Trichas, A., Vardinoyiannis, K., Sfenthourakis, S., and Mylonas, M. 2015. A review of phylogeographic analyses of animal taxa from the Aegean and surrounding regions. Journal of Zoological Systematics and Evolutionary Research, 53: 18-32.

Radenković, S., Vujić, A., Ståhls, G., Pérez-Bañón, C., Petanidou, T., and Šimić, S. 2011. Three new cryptic species of the genus Merodon Meigen (Diptera: Syrphidae) from the Island of Lesvos (Greece). Zootaxa, 2735: 35-56.

Ricarte, A. and Marcos García, M.A. 2017. A checklist of the Syrphidae (Diptera) of Spain, Andorra and Gibraltar. Zootaxa, 4216: 401-440.

Rondani, C. 1857. Dipterologiae Italicae Prodromus, 2. Species italicae ordinis Dipterorum in genera characteribus definita, ordinatim collectae, methodo analitica distinctae, et novis vel minus cognitis descriptis. Pars prima. Oestridae: Syrphidae: Conopidae. Tipographia Alexandri Stocim, Parma, Italy.

Rossi, P. 1807. Fauna Estrusca. Sistens insecta quae in provinciis Frolentina et Pisana praesertim collegit Petrus Rossius (Mantissae priore parte adjecta), iterum edita et annotatis aucta. Edition 2, Volume 2. Typis Thomae Masi \& Sociorum. Praesidum Facultate, Helmstedt, Germany.

Rotheray, G.E. 1994. Colour guide to hoverfly larvae (Diptera, Syrphidae) in Britain and Europe. Dipterists Digest, 9: 1-156.

Rotheray, G.E and Gilbert, F. 2011. The natural history of hoverflies. Forrest Text, Ceredigion, United Kingdom.

Šašić, Lj., Ačanski, J., Vujić, A., Ståhls, G., Radenković, , S., Milić, D., et al. 2016. Molecular and morphological inference of three cryptic species within the Merodon aureus species group (Diptera: Syrphidae). Public Library of Science One, 11: e0160001. https://doi.org/10.1371/ journal.pone.0160001.
Savić, I.R. 2008. Diversification of the Balkan fauna: its origin, historical development and present status. Advances in Arachnology and Developmental Biology, 12: 57-78.

Schiner, I.R. 1860. Vorlaufiger Commentar zum dipterologischen Theile der 'Fauna Austriaca', mit einer naheren Begrundung der in derselben aufgenommenen neuen Dipteren-Gattungen. II. Wiener Entomologische Monatsschrift, 4: 208-216.

Schiner, I.R. 1861. Fauna Austriaca: die Fliegen (Diptera) Nach der analytischen Methode bearb., mit der Characteristik almmilicher europäischer Gattungen, der Beechraibung aller in Deutschland vorkommenden Arten und der Aufzahlung aller bisher beschriebenen europaischen Arten. C. Gerolds Sohn, Vienna, Austria.

Simon, C., Frati, F., Beckenbach, A., Crespi, B., Liu, H., and Flook, P. 1994. Evolution, weighting and phylogenetic utility of mitochondrial gene sequences and a compilation of conserved polymerase chain reaction primers. Annals of the Entomological Society of America, 87: 651-701.

Speight, M.C.D. 2017. Species accounts of European Syrphidae 2017. Syrph the Net, the Database of European Syrphidae (Diptera), 97: 1-294.

Speight, M.C.D. and Sarthou, J.-P. 2017. StN keys for the identification of the European species of various genera of Syrphidae 2017/Clés StN pour la détermination des espèces Européennes de plusieurs genres des Syrphidae 2017. Syrph the Net, the Database of European Syrphidae (Diptera), 99: 1-139.

Speight, M.C.D. and Sommaggio, D. 2010. On the presence in Switzerland of Microdon myrmicae Schönrogge et al., 2002, Xanthogramma dives (Rondani, 1857) and X. stackelbergi Violovitsh, 1975 (Diptera: Syrphidae). Entomo Helvetica, 3: 139-145.

Ståhls, G., Vujić, A., Pérez-Bañón, C., Radenković, S., Rojo, S., and Petanidou, T. 2009. COI barcodes for identification of Merodon hoverflies (Diptera, Syrphidae) of Lesvos Island, Greece. Molecular Ecology, 9: 1431-1438. https://doi.org/10.1111/j.17550998.2009.02592.x.

Strobl, G. 1899. Spanische Dipteren.V. Theil. Wiener Entomologische Zeitung, 18: 144-148.

Szilády, Z. 1940. Über paläarktische Syrphiden. IV. Annales Musei historico-naturalis hungarici. Pars Zoologica, 33: 54-70.

Thompson, F.C. 1999. A key to the genera of the flower flies of the Neotropical Region including the descriptions of genera and species and a glossary of taxonomic terms. Contributions on Entomology, International, 3: 319-378.

Thompson, F.C and Rotheray, G.E. 1998. Family Syrphidae. In Contributions to a manual of Palaearctic Diptera. Higher Brachycera. Edited by L. Papp and B. Darvas B. Science Herald, Budapest, Hungary. Pp. 91-139.

Van Veen, M.P. 2004. Hoverflies of northwest Europe: identification keys to the Syrphidae. KNNV Publishing, Utrecht, The Netherlands. 
Violovitsh, N.A. 1975. Краткии обзор палеарктичерских видов рода Xanthogramma Schiner (Diptera, Syrphidae). [Brief survey of Palaearctic species of the genus Xanthogramma Schiner (Diptera, Syrphidae)]. Novye i Maloizvestiye Vidy Fauny Sibiri, 9: 90-106.

Vockeroth, J.R. 1969. A revision of the genera of the Syrphini (Diptera: Syrphidae). Memoirs of the Entomological Society of Canada, 62: 1-176.

Vujić, A. and Glumac, S. 1994. Fauna of hoverflies (Diptera: Syrphidae) of Fruška gora. Monografije Fruške gore. Matica srpska, Novi Sad, Serbia.

Vujić, A., Radenković, S., Ačanski, J., Grković, A., Taylor, M., Gökhan, S., and Hayat, R. 2015. Revision of the species of the Merodon nanus group (Diptera: Syrphidae) including three new species. Zootaxa, 4006: 439-462.

Vujić, A., Šimić, S., Milankov, V., Radović, D., Radišić, P., and Radnović, D. 1998. Fauna Syrphidae (Insecta: Diptera) of Obedska bara: importance and need of protection. Institute of Nature Protection of Serbia, Novi Sad, Serbia.
Vujić, A., Šimić, S., and Radenković, S. 2001. Endangered species of hoverflies (Diptera: Syrphidae) on the Balkan Peninsula. Acta Entomologica Serbica, 5: 93-105.

Vujić, A., Ståhls, G., Ačanski, J., Bartsch, H., 516 Bygebjerg, R., and Stefanović, A. 2013. Systematics 517 of Pipizini and taxonomy of European Pipiza Fallén: $\quad 518$ molecular and morphological evidence (Diptera, 519 Syrphidae). Zoologica Scripta, 42: 288-305. http:// 520 dx.doi.org/10.1111/zsc.12005.

Williston, S.W. 1887. Synopsis of the North American 522 Syrphidae. Bulletin of the United States National 523 Museum, 31: 1-335.

Zetterstedt, J.W. 1843. Diptera Scandinaviae, deposita 525 et descripta. Volume 2. Officina Lundbergiana, 526 Lund, Sweden. Pp. 441-894. 